\title{
A Short Review on Cardiotonic Steroids and Their Aminoguanidine Analogues
}

\section{Concepción P. Melero*, Manuel Medarde and Arturo San Feliciano}

Departamento de Química Farmacéutica, Facultad de Farmacia, Campus Miguel de Unamuno, 37007 Salamanca, Spain

Tel.: +34 9232945 28, Fax: +34 9232945 15, E-mail: medarde@gugu.usal.es

*Author to whom correspondence should be addressed.

Received: 14 November 1999 / Accepted: 9 December 1999 / Published: 21 January 2000

\begin{abstract}
A short review on cardiotonic steroids and their analogues is presented. The natural, semisynthetic and synthetic derivatives, as well as their mechanism of action and structure-activity relationships are shown, with a special reference to aminoguanidine derivatives.
\end{abstract}

Keywords: Digitalis glycosides analogues, structure-activity relationships, inotropic activity, $\mathrm{Na}+\mathrm{K}+-\mathrm{ATPase}$, aminoguanidine analogues.

1. Introduction

2. Mechanism of inotropic activity

2.1. $\mathrm{Na}^{+}, \mathrm{K}^{+}$-ATPase

2.2. Isoenzymes

3. Compounds displaying inotropic digitalis-like activity

3.1. Natural digitalis-like compounds

3.1.1. Digitalis-like glycosides in vegetal species

3.1.2. Digitalis-like glycosides in animal species

3.1.3. Natural digitalis-like glycosides recently isolated

3.2. Semisynthetic and synthetic digitalis-like compounds
3.2.1. Structure-activity relationships

3.2.2. Steroidal framework

3.2.3. Side chain at $\mathrm{C}-17$

3.2.4. Sugar

3.2.5. Other substituents at position C-3

3.2.6. Pregnane derivatives

3.3. Endogenous digitalis-like factors

4. Digitalis analogues bearing aminoguanidine moieties

4.1. Aminoguanidine moiety in drugs

4.2. Aminoguanidines in digitalis compounds

(C) 2000 by MDPI (http://www.mdpi.org). Reproduction is permitted for noncommercial purposes. 


\section{Introduction}

Digitalis glycosides are one of the most useful groups of drugs in therapeutics. The use of plants containing them has been known for a long time, but it was in 1785 when William Withering described the properties and medicinal uses of Digital [1], in particular for the treatment of dropsy, being aware of side effects and toxicity associated to high dosages. It was not until 1799 when the importance of the direct action of digitalis on the heart was considered [2].

Among the different cardiac glycosides present in Digitalis purpurea, gitaloxin (16-formylgitoxin) seemed to be the main responsible for therapeutic activity in the "foxglove tea" prescribed by Withering, due to its water solubility [3]. Digitoxin is present in similar concentration, but its low water solubility makes it more difficult to remove in aqueous extracts. The use of dried leaves of this plant has remained as the main treatment of cardiac failure for a long time.

Digoxin and its derivatives (acetyl- and methyldigoxin) are the cardiac glycosides most currently used in therapeutics.

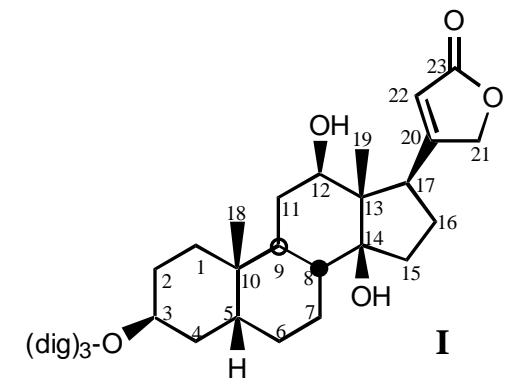

dig: digitoxose

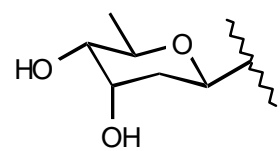

medig: 4'-O-methyldigitoxose
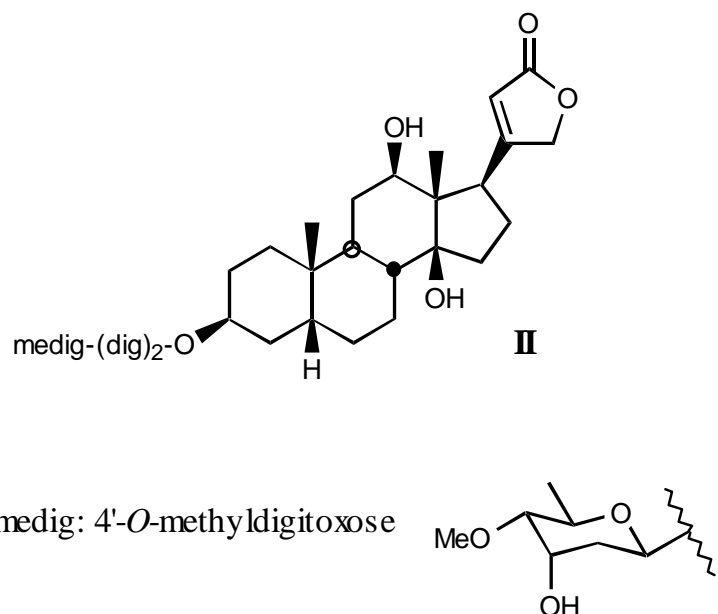

Figure 1. Structure of digoxin (I) and methyldigoxin (II).

\section{Mechanism of Inotropic Activity}

Digitalis glycosides can be defined as allosteric inhibitors of $\mathrm{Na}^{+}, \mathrm{K}^{+}$-ATPase, they seem to be chemically inert [4] and not covalently bound to the enzyme [5].

According to the still most widely accepted mechanism of action for digitalis type compounds [6], they act through inhibition of $\mathrm{Na}^{+}, \mathrm{K}^{+}$-ATPase, thus raising indirectly the intracellular $\mathrm{Ca}^{2+}$ concentration $\left(\left[\mathrm{Ca}^{2+}\right] \mathrm{i}\right)$. Therapeutic concentrations of digitalic compounds produce a moderate enzyme inhibition (about 30\%). When the cell is depolarised, there is a lower amount of enzymes available for the restoration of the $\mathrm{Na}^{+} / \mathrm{K}^{+}$balance. The remaining enzymes, non-inhibited, will act faster, because the high $\left[\mathrm{Na}^{+}\right]_{i}$ and the ionic balance must be restored before the following depolarisation, although it will 
take longer than if every enzyme were available. This lag causes a temporary increase of $\left[\mathrm{Na}^{+}\right]_{i}$, reaching higher concentrations than if ATPase activity were not partially inhibited. This temporary increase of $\left[\mathrm{Na}^{+}\right]_{i}$, modifies $\left[\mathrm{Ca}^{2+}\right]$ i through a Na${ }^{+} / \mathrm{Ca}^{2+}$ exchanger which allows $\mathrm{Na}^{+}$exit from the cell in exchange for $\mathrm{Ca}^{2+}$, or $\mathrm{Ca}^{2+}$ exit from the cell in exchange for $\mathrm{Na}^{+}$, depending on the prevailing $\mathrm{Na}^{+}$and $\mathrm{Ca}^{2+}$ electrochemical gradients [7]. This mechanism decreases exchange rate, or even reverses exchanger ion transport, being $\mathrm{Ca}^{2+}$ carried into the cell; anyway increasing $\left[\mathrm{Ca}^{2+}\right]_{i}$ and thus increasing contractile force.

When the concentration of digitalis compounds reaches toxic levels, enzyme inhibition is too high (>60\%), thus decreasing $\mathrm{Na}^{+}$and $\mathrm{K}^{+}$transport to the extent that the restoring of normal levels during diastole is not possible before the next depolarisation. Then, a sustained increase of $\left[\mathrm{Na}^{+}\right]_{i}$, and thus of $\left[\mathrm{Ca}^{2+}\right]_{i}$, gives rise to toxic effects (i.e. arrhythmia) of these compounds.

\section{1. $\mathrm{Na}^{+}, \mathrm{K}^{+}$-ATPase}

$\mathrm{Na}^{+}, \mathrm{K}^{+}$-ATPase (EC 3.6.1.37) or sodium pump, is a carrier enzyme present in almost every animal cell. Its physiological function is to maintain the $\mathrm{Na}^{+}$and $\mathrm{K}^{+}$electrochemical gradients through the cell membrane, keeping low $\mathrm{Na}^{+}$and high $\mathrm{K}^{+}$intracellular concentrations. Such concentrations of ions, their gradients and the consequent membrane potential determine a broad range of cellular functions, as excitability of nerves and muscle cells, secondary active transport and cellular volume regulation. It is estimated to consume about $25 \%$ of total ATP consumed at rest. The enzyme was discovered by Skou in 1957 [8].

The minimum functional entity of the $\mathrm{Na}^{+}, \mathrm{K}^{+}$-ATPase is formed by one $\alpha$ and one $\beta$ subunit. Each one of these subunits has different isoenzymes. The $\alpha$ subunit, with about $112 \mathrm{kD}$ and 1012 aminoacids, presents ten transmembrane segments, with $\mathrm{N}$-terminal and $\mathrm{C}$-terminal ends into the cytoplasmic side [9]. It is the catalytic subunit, undergoing conformational changes relating the energy produced from ATP hydrolysis and enzyme phosphorylation to the transport of cations [10]. The $\beta$ subunit (about $55 \mathrm{kD}$ and 300 aminoacids) has just one transmembrane segment, a short $\mathrm{N}$-terminal end towards the cytoplasmic side [11] and a large extracellular segment, bearing three disulphide bridges [12]. The $\beta$ subunit is the limiting one for the formation of the functional enzyme. $\alpha$ and $\beta$ subunits are synthesized in a different way and then they are included into the endoplasmic reticulum, where they are assembled, so determining the structural maturation of $\alpha$ subunit and the acquisition of its main functional features [13].

Both $\alpha$ and $\beta$ subunits are glycosidated. For the $\beta$ subunit, three to seven extracellular glycosidation sites have been found, depending on the considered isoenzyme. The $\alpha$ subunit is also glycosidated, although in this case by a monosaccharide (likely $N$-acetylglucosamine) and disposed towards the cytoplasmic side [14].

Moreover, there is a third $\gamma$ subunit, a membrane protein that interacts only with $\mathrm{Na}^{+}, \mathrm{K}^{+}$-ATPase, 
thus modulating the enzyme transport activity [15]. It has 12-14 kD mass, with about 58-68 aminoacids. This $\gamma$ subunit is an anphiphilic protein, bearing two structural domains: the amino terminal fragment is highly hydrophilic, carrying many charged aminoacids, and it must be extracellular; the carboxy terminal end is hydrophobic and likely lay across the membrane [16]. The $\gamma$ subunit only interacts with the $\alpha-\beta$ complex assembled and with functional ability, but not with separate $\alpha$ or $\beta$ subunits, inducing enzyme activity [15b].

In addition to the protein subunits negatively charged phospholipids are needed for enzyme activity [17], even when the cause of this is not clear. The membrane lipid bilayer could have a structural effect on the protein, maybe allowing it to carry out the necessary conformational changes for activity. A regulatory effect of phospholipids on the enzyme has not been shown.

$\mathrm{Na}^{+}, \mathrm{K}^{+}$-ATPase acts as a dimer $(\alpha \beta-\alpha \beta)$. The most widely accepted view related to such a dimer to act is a "flip-flop" model, in which both $\alpha$ subunits show complementary conformations [18]:

$$
\mathrm{E}_{1} \mathrm{E}_{2} \rightleftharpoons \mathrm{E}_{2} \mathrm{E}_{1}
$$

where $\mathrm{E}$ is the conformation of each $\alpha$ subunit. The observed co-operation between the members of the dimer [19] supports this model, which postulates that, when one of the $\alpha$ subunits is in the $\mathrm{E}_{1}$ conformation, the other one is necessarily in the $\mathrm{E}_{2}$. Different results have confirmed such a dimeric structure [20]. It seems that structural contacts between both $\alpha \beta$ units are needed for a complete catalytic activity of the enzyme.

Related to the transport activity, the enzyme takes out $3 \mathrm{Na}^{+}$in exchange for $2 \mathrm{~K}^{+}$carried into the cell. So, it allows the restoration of the appropriate $\mathrm{Na}^{+}: \mathrm{K}^{+}$ratio to maintain the transmembrane difference of potential [21]. It requires ATP and $\mathrm{Mg}^{2+}$ for activity. Binding of ligands to the enzyme, including a phosphorylation step, leads to conformational changes associated to $\mathrm{Na}^{+}$and $\mathrm{K}^{+}$transport. The supposed mechanism of action currently accepted was firstly proposed by Albers [22] and Post [23]. This mechanism includes a step in which the enzyme, after leaving out $3 \mathrm{Na}^{+}$and before taking in $2 \mathrm{~K}^{+}$, can be bound, and thus inhibited, by digitalis glycosides or their analogues, preventing $\mathrm{K}^{+}$binding and then stopping enzyme activity.

\subsection{Isoenzymes}

Classification of $\alpha$ subunit isoenzymes was initially based on the electrophoretic mobility of their polypeptides and their sensitivity towards digitalis glycosides. Currently three isoenzymes are differentiated, $\alpha_{1}, \alpha_{2}$ and $\alpha_{3}$ [24]. A fourth one has also been identified, although only at the genetic level [25]. The classification is based on the aminoacid number and the comparison between total and $\mathrm{N}$ terminal end aminoacids sequence.

Related to the affinity found for the different $\alpha$ isoenzymes towards digitalis glycosides, $\alpha_{1}$, present in almost every cell (it is the only one found in mammal kidney), shows the lowest affinity. $\alpha_{2}$ is largely found in skeletal and cardiac muscle, fatty tissue and stomach, and its affinity is higher than 
that of $\alpha_{1} . \alpha_{3}$ isoenzyme is mainly expressed at the brain, but it is also found in other vertebrate tissues. Its affinity toward digitalis glycosides is the highest.

Among $\beta$ isoenzymes, $\beta_{1}$ is present in all tissues [26], being the main isoenzyme found in mammal kidney. $\beta_{2}$ has been isolated from brain [27]. Recently, a third, $\beta_{3}$, has been identified in mammals, including the human being [28] and other animal species [29]. Any of $\alpha$ subunits can be assembled with any of $\beta$ subunits, giving thus rise to different enzyme complexes.

The different $\mathrm{Na}^{+}, \mathrm{K}^{+}$-ATPase isoenzymes come from different genes, which in turn show a significant chromosome dispersion [30]. Each one of the genes corresponding to each $\alpha$ or $\beta$ subunit is expressed at different rates and in different degrees, depending on the type of tissue and its development period [31].

$\mathrm{Na}^{+}, \mathrm{K}^{+}$-ATPase is regulated by $\mathrm{Na}^{+}$and $\mathrm{K}^{+}$concentrations, as well as by several hormones, as aldosterone, thyroid hormones, catecholamines and peptide hormones (vasopresin or insulin). Hormone regulation can be carried out at different levels, from cell surface to nucleus, and it can be expressed at short or long term [32].

\section{Compounds Displaying Inotropic, Digitalis-like Activity}

It is understood as "digitalis activity" the ability to inhibit $\mathrm{Na}^{+}, \mathrm{K}^{+}$-ATPase through acting onto the digitalis receptor, along with the ability to display a positive inotropic effect. Such an action is performed by several natural, semisynthetic and synthetic compounds [33]. Among the natural compounds, there are three groups: steroidal butenolides and pentadienolides, known as "cardiotonic steroids" or "digitalic compounds" and Erythrophleum alkaloids. The word "digitalis" is often used as a generic word for all cardiotonic steroids; similarly, the receptor for these compounds is generally known as "digitalis receptor".

Digitalis glycosides are compounds bearing a steroidal genin or aglycone with one or several sugar molecules attached to position C-3. In the case of toad venom, sugar is replaced by suberylarginine.

Fig. 1 depicts two of the most therapeutically used digitalis glycosides, digoxin and methyldigoxin. They represent a very important group of drugs for the treatment of heart failure, but display a main disadvantage, which arises from their narrow therapeutic index, so they have to be administered under a strict supervision. The proximity between effective and toxic doses is the cause of severe adverse effects to appear.

$\mathrm{Na}^{+}, \mathrm{K}^{+}$-ATPase inhibition at therapeutic doses is the cause of their positive inotropic effect, since only little changes in $\left[\mathrm{Na}^{+}\right]_{i}$ are required for a large effect on contractile force [34]. Apart from this activity, they can act on other physiological systems, leading to adverse effects [35].

\subsection{Natural digitalis-like compounds}

This kind of compounds are found in both animal and vegetal species [36], being the most well 
known those obtained from Digitalis. In most cases they are cis-anti-trans-syn-cis steroids, bearing a hydroxyl group at position $\mathrm{C} 14 \beta$, a butenolide or pentadienolide lactone ring at position $\mathrm{C} 17 \beta$ and a glycosidic moiety at position $\mathrm{C} 3 \beta$ carrying one or several sugar units.

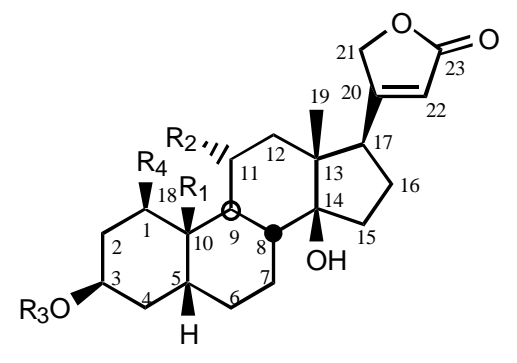

CARDENOLIDES

III Ouabain:

$\mathrm{R}_{1}: \mathrm{CH}_{2} \mathrm{OH}$

$\mathrm{R}_{2}: \mathrm{OH}$

$\mathrm{R}_{3}: \alpha, L$-rhamnose

$\mathrm{R}_{4}: \mathrm{OH}$

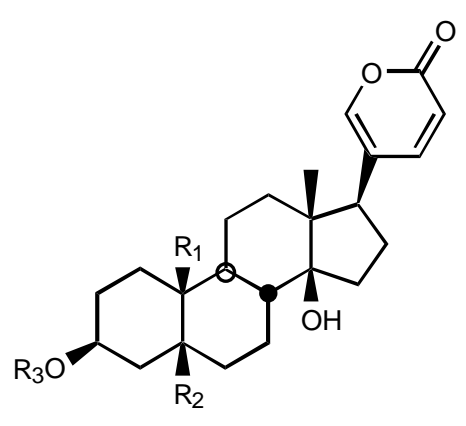

BUFADIENOLIDES

IV Hellebrine:

$\mathrm{R}_{1}: \mathrm{CHO}$

$\mathrm{R}_{2}: \mathrm{OH}$

$\mathrm{R}_{3}: \alpha, L$-rhamnose- $\beta, D$-glucose

Figure 2. Structure of cardenolides and bufadienolides.

Erythophleum alkaloids, some of them are shown in Fig. 3, display cardiotonic activity acting through the same mechanism, but have a different terpenic structure.
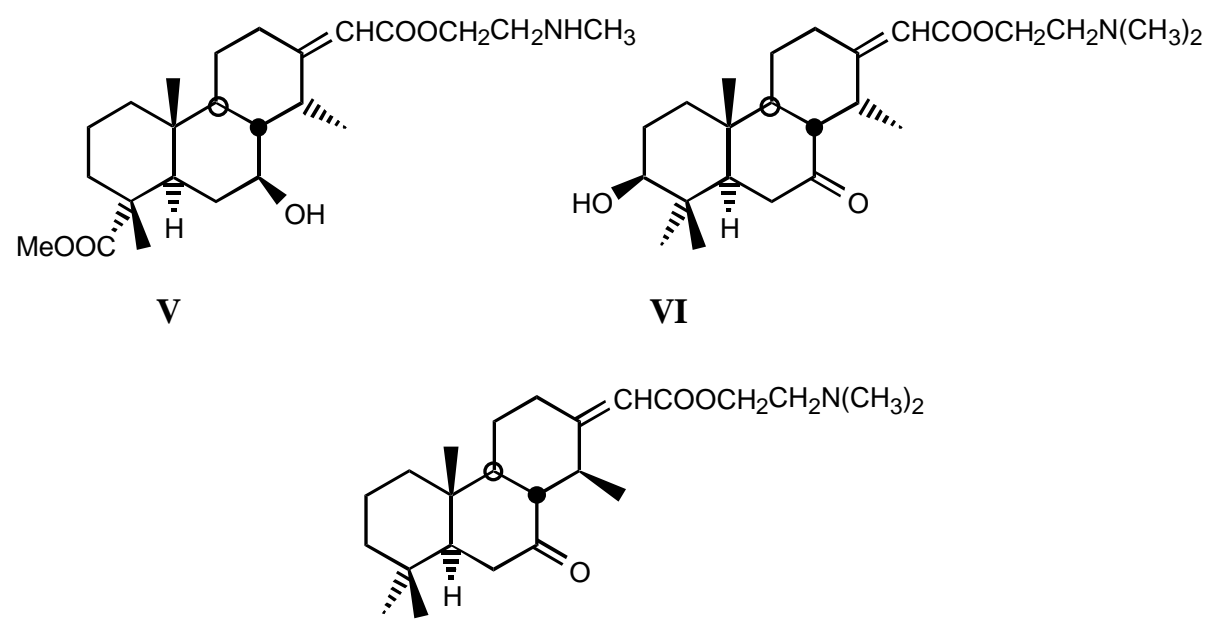

VII

Figure 3. Structure of some of Erythrophleum alkaloids displaying digitalis-like activity: erythrophleine (V), cassaine (VI) and coumingine (VII).

3.1.1. Digitalis-like glycosides in vegetal species

Vegetal species containing digitalis-like glycosides mainly belong to the Angiosperms, although 
some of them are found in certain Gymnosperms [37]. Digitalis-like glycosides isolated from different Fanerogam families [38] are shown in Table 1.

Table 1. Fanerogam species containing digitalis-like glycosides.

\begin{tabular}{|c|c|c|}
\hline Family & Species & Cardiotonic glycosides \\
\hline Apocynaceae & $\begin{array}{l}\text { Nerium oleander } \\
\text { Nerium odorum } \\
\text { Strophantus gratus, S. kombe, S. his- } \\
\text { pidus, } S . \text { sarmentosus, S. emini } \\
\text { Acokanthera schimperi (A. ouabä̈o), } \\
\text { A. venenata, A. abyssinica } \\
\text { Thevetia nereifolia } \\
\text { Thevetia yecotli } \\
\text { Cerbera odollam } \\
\text { Cerbera tanghin } \\
\text { Adenium boehmanianum } \\
\end{array}$ & $\begin{array}{l}\text { Oleandrin, neriin, neriantin. } \\
\text { Odoroside A and B. } \\
\text { Ouabain (G-strophantin), cymarin, sarmentocyma- } \\
\text { rin, periplocymarin, K-strophantin. } \\
\text { Ouabain. } \\
\text { Thevetin, cerberin, peruvoside. } \\
\text { Thevetosin, thevetin A. } \\
\text { Cerberin. } \\
\text { Tanghinin, deacetyltanghinin, cerberin. } \\
\text { Echujin, hongheloside G. }\end{array}$ \\
\hline Asclepiadaceae & $\begin{array}{l}\text { Periploca graeca } \\
\text { Periploca nigrescens } \\
\text { Xysmalobium undulatum } \\
\text { Gomphocarpus fruticosus } \\
\text { Calotropis procera } \\
\end{array}$ & $\begin{array}{l}\text { Periplocin. } \\
\text { Strophantidin, strophantidol, nigrescin. } \\
\text { Uzarin. } \\
\text { Uzarin. } \\
\text { Calotropin. }\end{array}$ \\
\hline Brassicaceae & Cheiranthus cheiri & Cheiroside A, cheirotoxin. \\
\hline Celastraceae & $\begin{array}{l}\text { Euonymus europaeus, E. atropur- } \\
\text { pureus }\end{array}$ & Eounoside, euobioside, euomonoside. \\
\hline Crassulaceae & $\begin{array}{l}\text { Kalanchoe lanceolata } \\
\text { Kalanchoe tomentosa } \\
\text { Kalanchoe tubiflorum } \\
\text { Kalanchoe pinnatum } \\
\text { Tylecodon wallichii } \\
\text { Tylecodon grandiflorus } \\
\text { Cotyledon orbiculata }\end{array}$ & $\begin{array}{l}\text { Lancetoxin A and B. } \\
\text { Kalanchoside. } \\
\text { Bryotoxin A-C. } \\
\text { Bryotoxin C, bryophyllin B. } \\
\text { Cotiledoside. } \\
\text { Tyledoside A-D, F and G. } \\
\text { Orbicuside A-C. }\end{array}$ \\
\hline Fabaceae & Coronilla sp. & $\begin{array}{l}\text { Alloglaucotoxin, corotoxin, coroglaucin, glau- } \\
\text { corin. }\end{array}$ \\
\hline Iridaceae & $\begin{array}{l}\text { Homeria glauca } \\
\text { Moraea polystachya, M. graminicola }\end{array}$ & $\begin{array}{l}\text { Scillirosidin derivatives. } \\
\text { Bovogenin A derivatives. }\end{array}$ \\
\hline Liliaceae & $\begin{array}{l}\text { Urginea rubella } \\
\text { Convalaria majalis } \\
\text { Bowiea volubilis, B. kilimand- } \\
\text { scharica }\end{array}$ & $\begin{array}{l}\text { Scillarene A and B, scilliroside, scillarenia, scillia- } \\
\text { cinoside, scilliglaucoside, scilliglaucosidin, scil- } \\
\text { liphaeosidin, scilliphaeoside, scillirosidin, scilliru- } \\
\text { brosidin, scillirubroside, proscillaridin A. } \\
\text { Rubelin. } \\
\text { Convalloside, convallatoxin. } \\
\text { Bovoside A, glucobovoside A, bovoruboside. }\end{array}$ \\
\hline Moraceae & Antiaria africana, A. toxicaria & Antiarin $\alpha$. \\
\hline Ranunculaceae & $\begin{array}{l}\text { Helleborus niger, } H . \text { viridis, } H . \text { foeti- } \\
\text { dus } \\
\text { Adonis vernalis, A. aestivalis, } A . \\
\text { autumnalis, A. flammea }\end{array}$ & $\begin{array}{l}\text { Helleborein, helleborin, hellebrin. } \\
\text { Adonidin, adonin, cymarin, adonitoxin. }\end{array}$ \\
\hline Santalaceae & Thesium lineatum & Thesiuside. \\
\hline Scrophulariaceae & Digitalis purpurea, D. lanata & $\begin{array}{l}\text { Digitoxin, gitoxin, gitalin, digoxin, F-gitonin, } \\
\text { digitonin, lanatoside A-C. }\end{array}$ \\
\hline
\end{tabular}


3.1.2. Digitalis-like glycosides in animal species

They occur mainly in toads, either as free genins (bufagins) or bound to suberylarginine (bufotoxins). The genins are shown in Table 2.

Table 2. Toad species having digitalis-like compounds.

\begin{tabular}{ll}
\hline Species & Genins \\
\hline Bufo vulgaris & Bufotalin, bufotalinin, bufotalidin. \\
Bufo japonicus & Gamabufagin. \\
Bufo gargarizans & Cinobufagin. \\
Bufo marinus & Marinobufagin. \\
Bufo arenarum & Arenobufagin. \\
Bufo regularis & Regularobufagin. \\
Bufo valliceps & Vallicepobufagin. \\
Bufo quercicus & Quercicobufagin. \\
Bufo viridis & Viridibufagin. \\
Bufo sp. & Pseudobufotalin. \\
\hline
\end{tabular}

They have also been isolated from glow-worms and snakes, although in these cases only as genins.

\subsubsection{Natural digitalis-like glycosides recently isolated}

Currently, this kind of compounds continues to be isolated from vegetal and animal species. Some of such compounds identified during the last decade are:

From Digitalis canariensis: digitoxigenin-3-O- $\beta$-glucosyl-(1->4)-3'- $O$-acetyl- $\beta$ - $D$-digitoxoside [39].

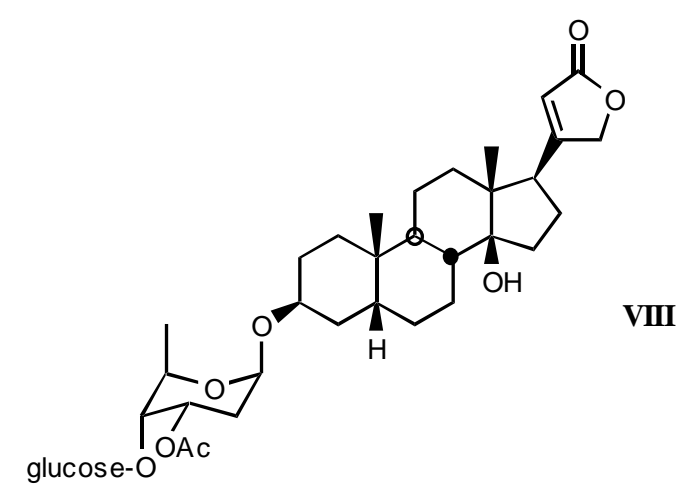

Figure 4. Structure of digitoxigenin-3- $O$ - $\beta$-glucosyl-(1->4)-3'- $O$-acetyl- $\beta$ - $D$-digitoxoside (VIII). 
From Acokanthera spectabilis: acobioside A and 14-O-acetylacovenioside C [40].

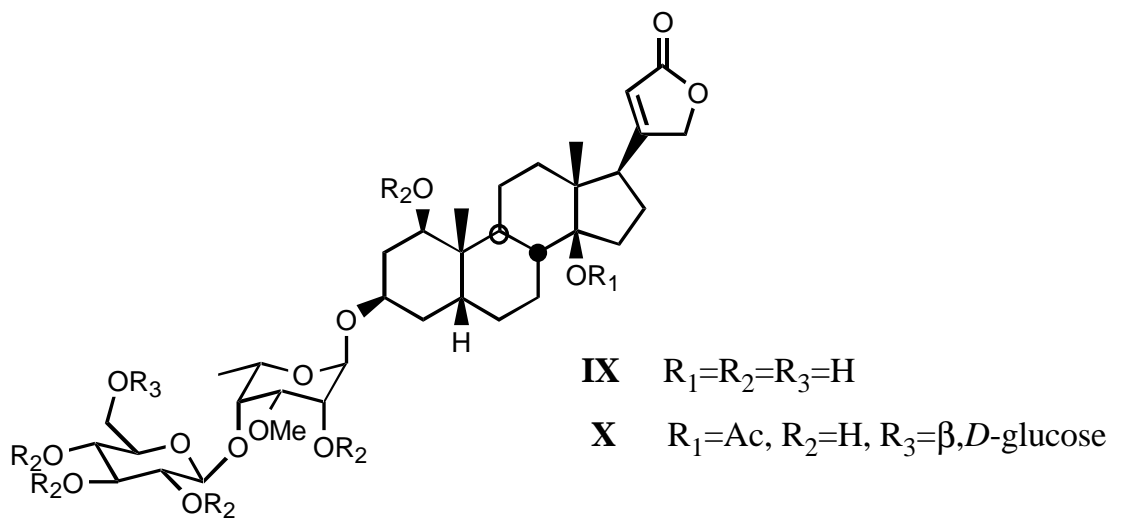

Figure 5. Structure of acobioside A (IX) and 14- $O$-acetylacovenioside $\mathrm{C}(\mathbf{X})$.

From Asclepias vestita: 5,6-dehydrocalactin [41].

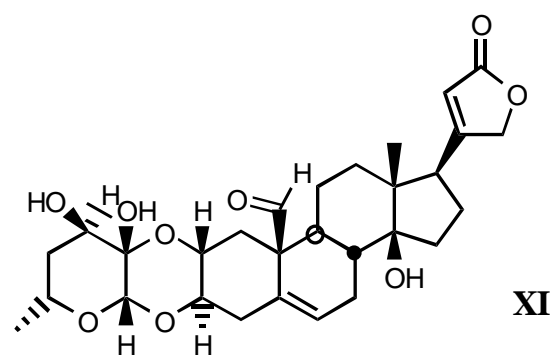

Figure 6. Structure of 5,6-dehydrocalactine (XI).

From Nierembergia aristata [42]:

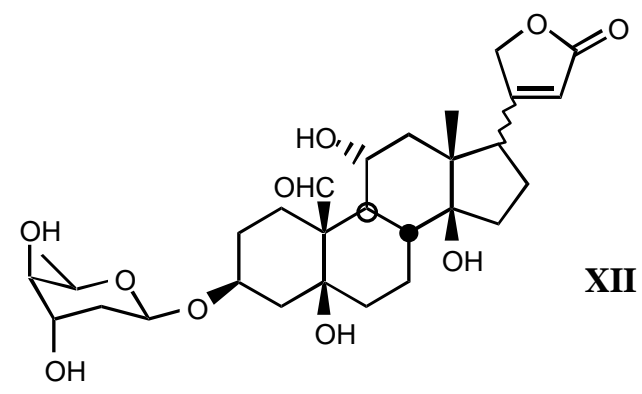

Figure 7. Digitalis-like glycoside with cardiotonic activity isolated from Nierembergia aristata (XII). 
From Periploca sepium [43]:

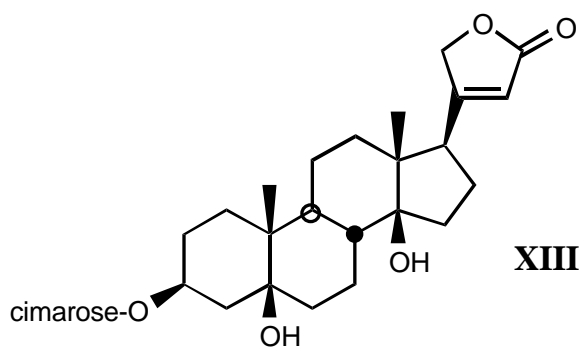

Figure 8. Digitalis-like glycoside displaying cardiotonic activity isolated from Periploca sepium (XIII).

From Apocynum cannabinum [44]:

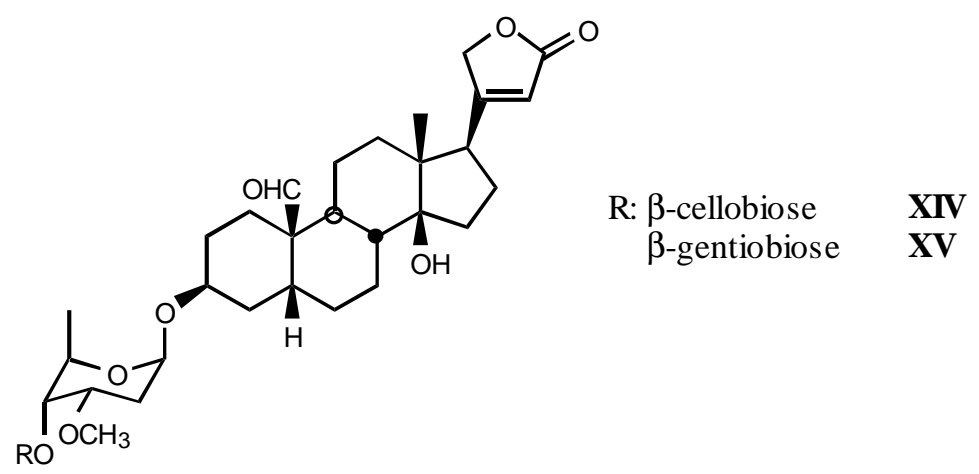

Figure 9. Cardiotonic digitalis-like glycosides isolated from Apocynum cannabinum (XIV and XV).

During the last decade some other compounds of natural origin have been described. Nevertheless, their structure is different from that of compounds above described, and their mechanism of action, even when they display positive inotropic activity, do not involve acting onto digitalis receptor, but on other physiological systems, so they have not been included in this review.

\subsection{Semisynthetic and synthetic digitalis-like compounds}

Apart from digitalis-like compounds isolated from natural sources, there is a wide range of semisynthetic and synthetic analogues. These have been prepared by introducing different modifications on the original compounds, thus trying to determine which are the essential structural requirements for displaying cardiotonic activity and, on the other hand, to obtain derivatives with less toxicity, i.e., a broader therapeutic index. From the research on those compounds some structure-activity relationships (SAR) have been deduced. 


\subsubsection{Structure-activity relationships (SAR)}

SAR studies on steroidal cardiac glycosides [6][45] have led to the conclusions exposed below and the proposal for the existence of a receptor model containing different areas:

- A first one for the interaction with the steroidal framework, through hydrophobic binding.

- A second one for interaction with the lactone ring showing two binding points, an electrostatic interaction through the electron-deficient $\beta$-Carbon atom and a Hydrogen bond to the carbonylic Oxygen atom.

- A third one for interaction with sugar: hydrophobic binding through C5' and Hydrogen bond to C3'-OH.

- A forth one, from which, Hydrogen bonds to the $\beta$ face of the molecule could be established, in the case of having such groups.

\subsubsection{Steroidal framework}

In Digitalis-like glycosides, the steroidal framework is considered the pharmacophoric moiety, re-

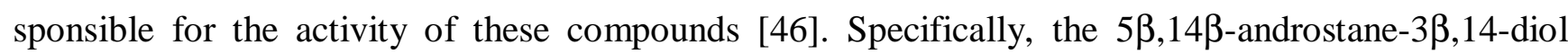
skeleton has shown the same binding properties to the enzyme as digitalis compounds. As deduced from energetic calculations related to pharmacophore-receptor interaction, most of interaction energy arises from Van der Waals forces, which are very dependent on the distance [47]. Electrostatic molecular potential calculations, in turn, show that the steroidal framework is surrounded by a positive field, its charge arising from $\mathrm{C}-\mathrm{H}$ bonds, so it is supposed that aminoacids interacting with such a moiety should bear negative charges.

Moreover, structure bending, owed to the cis junctions between $\mathrm{A} / \mathrm{B}$ and $\mathrm{C} / \mathrm{D}$ rings, is an essential request for the highest interaction energy. Any change on that spatial disposition, modifying A and/or $\mathrm{B}$ rings related to $\mathrm{B}-\mathrm{C}$ plane, decreases the interaction energy [48]. This can be observed in the case of variation of the configuration $5 \beta$ to $5 \alpha$ or introduction of a $\Delta^{5}$ double bond, even when such a decrease is not very high. Similarly, a higher interaction energy decrease is observed if the geometry of D ring

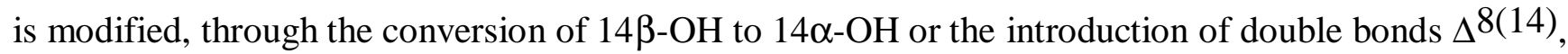
$\Delta^{14}, \Delta^{14,16}, \Delta^{8,14,16}$ or $\Delta^{16}$. Such a decrease can be partially related to the flexibility conferred to the molecule by double bonds, in contrast with the rigidity of the steroidal framework. This fact can also explain some reduction in the specificity (discrimination among ATPases from different origins).

The presence of $\mathrm{OH}$ groups at different positions of the steroidal skeleton reduces, in general, the interaction energy, though it depends on the location and spatial disposition of such $\mathrm{OH}$ groups. This fact seems to be due to decreasing of steroidal positive potential field and steric hindrance. Furthermore, the effect of $\mathrm{OH}$ groups varies depending on whether the cardenolide or the pregnane framework are considered, which in turn could depend on the characteristics of the side chain at position C17, 
bulky and rigid or small and flexible. The $\mathrm{OH}$ group at position $\mathrm{C} 14 \beta$ is not an essential feature for inotropic activity, although when it is replaced by a Hydrogen atom potency decreases considerably [49]. Particularly, an $\mathrm{OH}$ group at position $\mathrm{C} 16 \beta$ reduces potency in a large extent, but if such an $\mathrm{OH}$ is esterified, potency increases. Several explanations have been proposed for this fact: the existence of a binding site for such ester or the presence of the unesterified $16 \beta-\mathrm{OH}$ group that would make possible a Hydrogen bond to the $\mathrm{OH}$ at position $\mathrm{C} 14 \beta$, producing a modification of the spatial disposition of ring $\mathrm{D}$ and thus the interaction of the lactone with its receptor [50].

Conversion of $3 \beta-\mathrm{OH}$ to $3 \alpha-\mathrm{OH}$ brings about a strong decrease of interaction energy; such a decrease is not so high if conversion goes towards 3-ketone or ester formation. The later effect can be owed to transformation of an unpaired Hydrogen bonding moiety into a strong Hydrogen bondacceptor one.

The change of the A/B junction does not necessarily imply a decrease of activity of aglycones, although it does for the corresponding glycosides, indicating that the main influence of $\mathrm{A} / \mathrm{B}$ junction arises from its ability to place the sugar into a suitable position.

Although it was firstly thought that only C/D cis steroids $(5 \beta, 14 \beta)$ could display cardiotonic activity, it has been observed later that some $C / D$ trans steroids $(5 \beta, 14 \alpha)$ show a similar or even stronger interaction with the digitalis receptor. The low potency of pregnanes with this configuration is owed to the side chain at $\mathrm{C} 17$, which is not contributing to interaction, and its replacement by a lactone ring does not increase such energy, being even possible to cancel out the activity. Thus, the spatial disposition of either the lactone ring or its equivalent moiety is essential for digitalis activity.

In the same way, D-seco and D-homosteroids have been evaluated [51], concluding that the D ring is not essential for cardiotonic activity. Nevertheless, for D-homoderivatives, less potent than their parent homologues, C/D cis junction is needed for displaying cardiotonic activity, similarly to classic digitalis compounds.

Simplified cardiotonic steroid analogues with a non-steroidal framework have also been synthesized and evaluated as inotropic agents. For instance, diterpene analogues, lacking the D ring, bearing A/B trans junction and other structural features considered important for positive inotropic activity, as the lactone ring and the hydroxyl group at $\mathrm{C} 14 \beta$, have been synthesized [52]. However, none of these diterpene analogues displayed a significant inotropic activity.

Other simplified analogues with non-steroidal framework are hydroindene derivatives, which mimic C/D cis rings. Moreover, they carry a hydroxyl group at an equivalent position to the C14 $\beta$ of steroids, and an open chain fragment replacing the lactone ring at the equivalent position. Several families of these analogues have been synthesized [53] and their conformational study has been carried out, taking into account the stability of different conformers depending on substituents attached to the hydroindene skeleton [54]. Inotropic activity of these analogues has also been evaluated [55]. 


\subsubsection{Side chain at $\mathrm{C} 17$}

The lactone ring at $\mathrm{C} 17 \beta$ has been considered for a long time to be responsible for inotropic activity, bringing about conformational changes on the enzyme that would give rise to its inhibition [56]. Indeed, that is the most differentiating feature from steroid hormones, and its contribution to the interaction energy ( -20.5 or $-27.6 \mathrm{~kJ} / \mathrm{mol}$ for the butenolide and pentadienolide, respectively) is as large as that of the whole steroidal framework $(-22.7 \mathrm{~kJ} / \mathrm{mol})$ [57]. Then, a very significant research was carried out on simple lactones, with the aim of assigning the cardiotonic activity of digitalis compounds to the lactone moiety [58], but none of them showed such an activity. This, together with the fact that there is not a "pre-existing" binding site for the lactone ring on the receptor, indicates that for large energetic contribution of such lactone ring it is required the "building up" of its binding site through a conformational change promoted by the steroidal binding.

Surrounding the lactone ring there is a negative electrostatic potential. One of the interaction forces between the lactone ring and its binding site seems to be a Hydrogen bond, owing to Oxygen ability to act as acceptor for such bonds. In fact, there is a high negative potential surrounding both lactone Oxygen atoms [59]. Such Oxygen atoms can participate in up to two Hydrogen bonds, thus increasing directionality of bond formation [60]. Together with those considerations, involving of lactone ring in formation of Hydrogen bonds is confirmed by the fact that most of the substituents at $\mathrm{C} 17 \beta$ (except $\mathrm{OH}, \mathrm{OCOMe}$ and $\mathrm{COOMe}$ ) increase interaction energy, but the highest increase is found with butenolide and pentadienolide [45b].

The lactone ring has been replaced by other heterocycles in some semisynthetic derivatives. In the case of pyridine or piridazine rings, energetic contribution is only partially kept, even when Nitrogen can also act as Hydrogen bond acceptor. Replacement by furan decreases interaction energy by 2.8 $\mathrm{kJ} / \mathrm{mol}$, the approximate energetic contribution of lactone Hydrogen bond [57]. Replacement of Oxygen by Nitrogen (furanone by pyrrolidone) decreases in large extent enzyme inhibition [58b], even when replacement by Sulphur does not modify interaction energy (because Sulphur can also act as Hydrogen bond acceptor [57]).

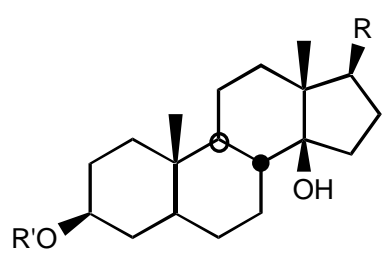

R:

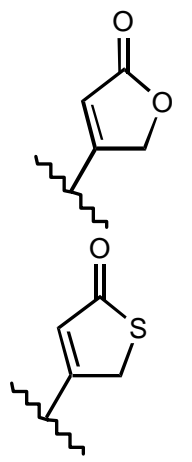

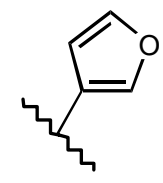

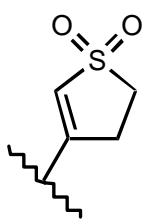

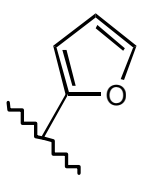
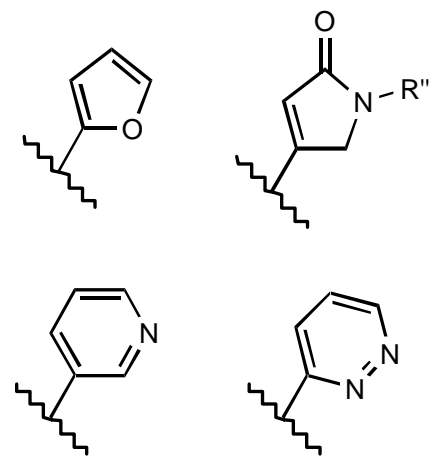

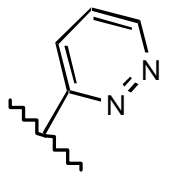

Figure 10. Semisynthetic derivatives with heterocycles replacing the lactone ring. 
Some other modifications carried out on the lactone ring [46a] [61] are shown in Fig, 11.
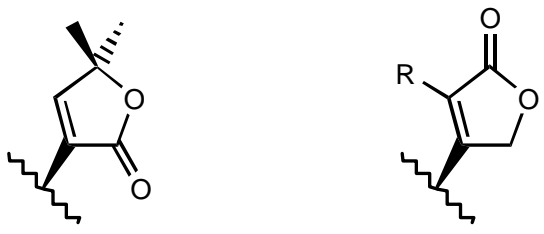

$\mathrm{R}: \mathrm{Me}, \mathrm{CH}=\mathrm{CH}-\mathrm{CH}_{3}$,

$\left(\mathrm{CH}_{2}\right)_{\mathrm{n}}-\mathrm{OH}, \mathrm{OR}, \mathrm{OCOR}$

Figure 11. Semisynthetic derivatives with lactone ring modifications.

In addition, it has to be considered the strong dependence of Hydrogen bond energy on distance and angle of such a bond, which can explain the large variations observed when modifying spatial disposition of carbonylic Oxygen [62], e.g., changing the attachment position of the lactone ring from C20 to C22 (actodigin and related compounds [63]) or to C21.

Reduction of the $\Delta^{20(22)}$ double bond, leading to loss of flat geometry at such bond and to modifications of spatial disposition of Oxygen atoms, decreases the interaction energy. This can be explained partially by changes of Hydrogen bond accepting properties of Oxygen atoms and partially to steric hindrance.

Rotational energy barrier for C17-C20 bond is not high in comparison with the interaction energy between cardenolides and their receptor [64], so the proximity of the compound to its asymmetric receptor potential, which determines the stereospecificity of binding site, can promote the conformational disposition of the lactone ring in the binding to receptor. Data coming from different studies suggest that such conformation is 14,21, i.e., H21 and HO14 in the same direction. Moreover, it seems that a certain degree of conformational freedom is required for such interaction, so compounds can adopt the most suitable 14,21 conformation for binding to the receptor.

Replacement of the lactone ring by open chains, bearing an electron rich heteroatom and a conjugated double bond gives high interaction energies. Thomas et al. suggested that, together with a Hydrogen bond, there is a dipole-dipole interaction in lactone binding [6], but they place it at C20, while it is very much likely located at double bond, showing a strong electronic density decrease area at the butenolide plane [65].

Those open chains at $\mathrm{C} 17 \beta$ can adopt, through rotation about $\mathrm{C} 22-\mathrm{C} 23$ bond, a butenolide-like conformation, thus contributing similarly to the interaction with the receptor [66]. $\alpha, \beta$-unsaturated methyl ester is, after $\alpha, \beta$-unsaturated nitrile, the most potent analogue. Nevertheless, $\alpha, \beta$-unsaturated esters show decreased potency with increasing size in alkyl chain (Fig. 12). 


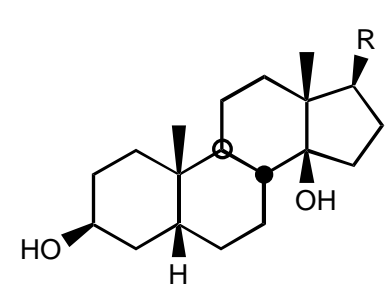

\begin{tabular}{|c|c|}
\hline $\mathrm{R}$ & $\begin{array}{l}\text { Relative } \\
\text { potency }\end{array}$ \\
\hline Unsaturated lactone (digitoxigenine) & 1 \\
\hline$-\mathrm{CH}=\mathrm{CH}-\mathrm{CN}$ & 0,66 \\
\hline$-\mathrm{CH}=\mathrm{CH}-\mathrm{COOCH} 3$ & 0,49 \\
\hline$-\mathrm{CH}=\mathrm{N}-\mathrm{NH}-\mathrm{C}\left(\mathrm{NH}_{2}\right)=\mathrm{NH}$ & 0,20 \\
\hline$-\mathrm{CH}=\mathrm{C}\left(\mathrm{CH}_{3}\right)-\mathrm{COOCH} 3$ & 0,04 \\
\hline$-\mathrm{CH}=\mathrm{CH}-\mathrm{COOCH}{ }_{2} \mathrm{CH} 3$ & 0,03 \\
\hline$-\mathrm{CH}=\mathrm{CH}-\mathrm{COOCH}\left(\mathrm{CH}_{3}\right) 2$ & 0,005 \\
\hline$-\mathrm{CH}=\mathrm{CH}-\mathrm{COOC}_{6} \mathrm{H} 5$ & 0,004 \\
\hline$-\mathrm{CH}=\mathrm{CH}-\mathrm{CH}=\mathrm{CH}-\mathrm{COOCH}_{3}$ & 0,004 \\
\hline
\end{tabular}

Figure 12. Structure and relative potency of some semisynthetic digitoxigenin derivatives, substituted at $\mathrm{C} 17 \beta$ [67].

Insertion of a methylene between $\mathrm{C} 17$ and $\mathrm{C} 20$, or modification of the lactone ring attachment from $\mathrm{C} 17 \beta$ to $\mathrm{C} 17 \alpha$ lead to the loss of lactone ring contribution to interaction energy [68]. Several inactive derivatives modified at the $\mathrm{C} 17$ chain are shown in Figure 13.

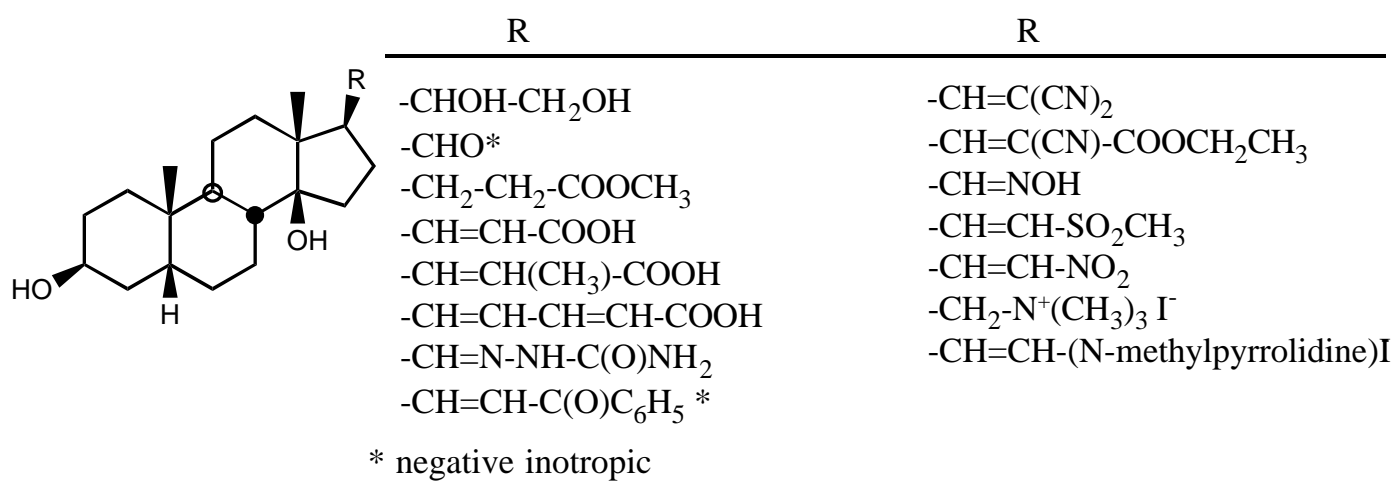

Figure 13. Structure of some inactive semisynthetic digitalis-like derivatives, substituted at C17 $\beta$.

Aminoacids involved in lactone binding have to be close to the steroid binding site, located at the first $\mathrm{Na}^{+}, \mathrm{K}^{+}$-ATPase transmembrane segment. It is supposed that the Hydrogen bonds to the lactone Oxygen atoms are established by the amide groups of Gln119 or Asn122. The strong electronic deficiency borne at the butenolide plane could be complemented by the negative charge of Asp121, which is closely related to ouabain binding.

\subsubsection{Sugar}

Sugar attachment to the steroid modifies both pharmacokinetics and pharmacodynamics of digitalis glycosides. Free genins are absorbed faster than glycosides, stored in larger extent at the central nervous system and more easily metabolized to less active $3 \alpha-\mathrm{OH}$ epimer, in consequence the action of free genins is fast and short-lasting but no free of toxic effects. 
Significance of the sugar moiety for digitalis activity is well established, though sugars by themselves do not display any activity. Indeed, it seems that rhamnose and glucose do not bind to $\mathrm{Na}^{+}, \mathrm{K}^{+}-$ ATPase [69]. Sugar binding site is not "pre-existing" at the receptor, coming up during glycoside binding. The observed potency sequence is: monosaccharide-aglycone $>$ disaccharide-aglycone $>$ trisaccharide-aglycone > aglycone, indicating that only the first sugar molecule is involved in receptor binding [70]. Decreasing of the interaction energy related to the second and third sugar units can be due to increased rotational and translational entropies. The distance from the lactone carbonylic Oxygen to the Oxygen at C4' of the first sugar is close to $19 \AA$, thus indicating the receptor length.

There is a wide variety of sugars carried by digitalis glycosides, from the very often found in Nature, as glucose, galactose, mannose or rhamnose, to other not as usual, as digitoxose, thevetose, cymarose, allose or altrose. Both $\beta$ - $D$ - and $\alpha$ - $L$-sugars may contribute to increase the interaction energy.

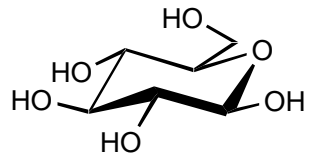

$\beta$-D-glucose

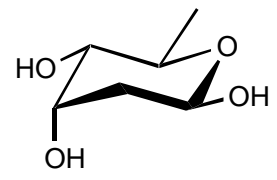

$\beta$-D-digitoxose

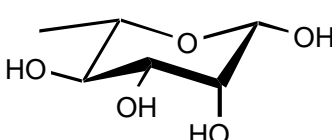

$\alpha$-L-rhamnose

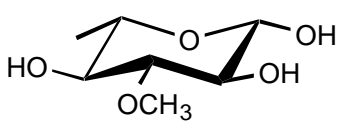

$\alpha$-L-thevetose

Figure 14. Structure of some of the sugars present in digitalis glycosides.

In relation with the sugar type, highest potency is conferred by 6'-deoxysugars, so 5'-methyl group is important for binding. Moreover, an equatorial 4'-OH group is also important for binding, and not a 3'-OH, while the 4'-OH axial group is much less effective [71]. In spite of these general considerations, the influence of different substituents depends on the regarded sugar [72]. Sugars as rhamnose or thevetose can increase potency several times, while mannose has no effect [73]. On the other hand, furanose rings do not seem to be as active as pyranose rings.

The highest interaction with the receptor is found with $\alpha$-L-rhamnose and its 4'-amino-4'-deoxy derivative (although if other sugars are analyzed, potency depends on the aglycone structure). So, it seems that sugar interaction comes through 4'-OH or 4'- $\mathrm{NH}_{2}$ of rhamnose and receptor aminoacids acting as Hydrogen bond donors. Since the $\mathrm{NH}_{2}$ group is even better than the $\mathrm{OH}$ group, it is supposed that binding to an acid proton (i.e., a carboxylic group), would represent the strongest bond [65]. In fact, attachment to C3 $\beta$ of substituents such as glucuronide, sulphate or esters from carboxylic acids decreases or eliminates activity.

As pointed out before, replacement of sugars by aminosugars sometimes increases activity. For example, compounds shown in Fig. 15 have a better therapeutic index and a 10-fold higher potency than digoxin [74]. 


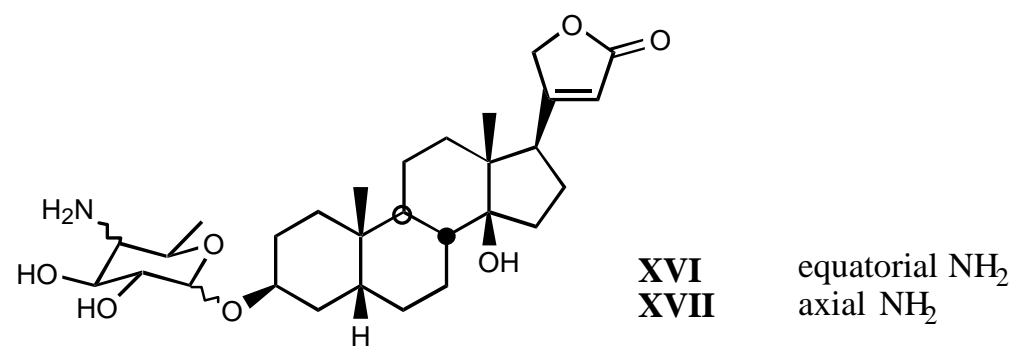

Figure 15. Structure of some derivatives bearing aminosugars.

Digitalis-like compounds bearing two-point attached sugars can also display high activity, e.g., gomphoside (Fig. 16).

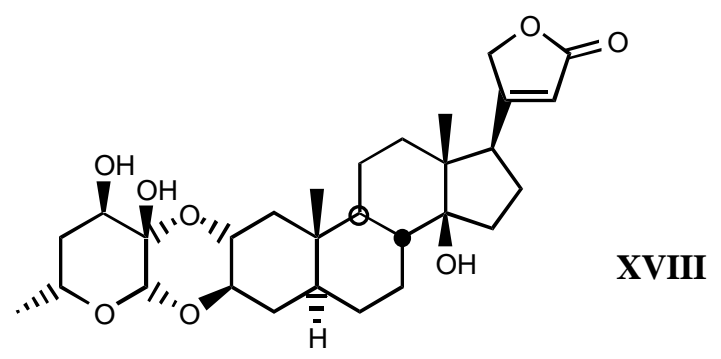

Figure 16. Structure of gomphoside XVIII.

Some studies suggest that recognition of certain structural sugar features depends on the studied isoenzyme, but in the case of the main structural features such a dependence does not exist [75].

\subsubsection{Other substituents at position $\mathrm{C} 3$}

Although most of the described substituents are sugars, other moieties have been attached at that position. There have been mainly described esters (Fig. 17) showing different lengths and functionalizations at the end of the chain, alcohol, ketone, carboxylic acid and amide [6]. The amide series has elicited the highest activity.

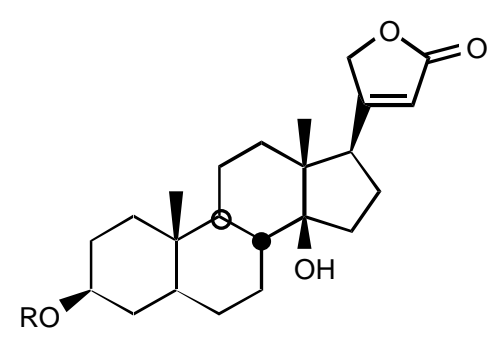
R: - $\mathrm{CO}-\left(\mathrm{CH}_{2}\right)_{\mathrm{n}}-\mathrm{COOH}$
$-\mathrm{CO}-\left(\mathrm{CH}_{2}\right)_{\mathrm{n}}-\mathrm{O}-\left(\mathrm{CH}_{2}\right)_{\mathrm{n}}-\mathrm{COOH}$
$-\mathrm{CO}-\left(\mathrm{CH}_{2}\right)_{\mathrm{n}}-\mathrm{CONH}_{2}$
$-\mathrm{CO}-\left(\mathrm{CH}_{2}\right)_{n}-\mathrm{COO}-\left(\mathrm{CH}_{2}\right)_{n}-\mathrm{CH}_{2} \mathrm{OH}$
$-\mathrm{S}-\left(\mathrm{CH}_{2}\right)_{\mathrm{n}}-\mathrm{NR}_{2}$
$-\mathrm{NR}_{2}$

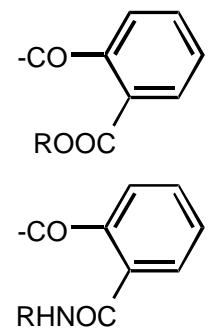

Figure 17. Structure of some derivatives bearing different moieties at C3. 
Recently, some $3 \beta$-aminoalkylthio moieties have been introduced, with the aim of checking the influence of a free or alkylated amino group [76], showing in most cases a higher affinity than for the corresponding $3 \beta-\mathrm{OH}$ and $3 \beta-\mathrm{SH}$ derivatives. Previously, there has been only described a strophantidin derivative of this type [77], with affinity higher than that of the corresponding genin.

Some C3-amino derivatives have also been described [78].

The sugar binding site would be located at the third transmembrane segment, which includes aminoacids such as Glu307 and Tyr308. Both of them bear Hydrogen atoms than can be used for Hydrogen bonding [79]. Then, steroid binding to its site promotes folding of the first transmembrane segment to the third one, building up a three-dimensional environment that becomes the whole digitalis receptor. Such a conformational change would affect the geometry of the catalytic centre, dramatically decreasing enzyme affinity for its substrate, ATP [80].

\subsubsection{Pregnane derivatives}

Pregnane derivatives eliciting digitalis-like activity are interesting because they can represent a structural possibility for endogenous digitalis-like compounds [81]. There have been identified some pregnane derivatives which could display such an activity, and their ability to displace ${ }^{3} \mathrm{H}$-ouabain from its $\mathrm{Na}^{+}, \mathrm{K}^{+}$-ATPase binding site has been evaluated [82]. These results gave rise to a systematic search for synthetic pregnane analogues.

Thus, several families of 5 $\beta, 14 \beta$-pregnane and 21-norpregnane derivatives, carrying at C20 hydroxyl, amine, acetamide, nitro and other functional groups, were prepared (Fig. 18). Both series have shown a very similar activity related to inhibition of ${ }^{3} \mathrm{H}$-ouabain binding [83].

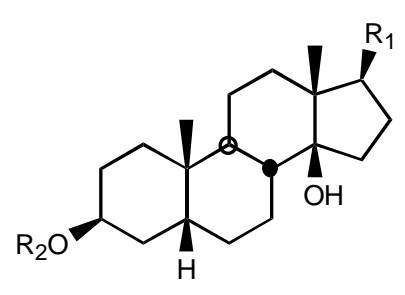

\begin{tabular}{lll}
\multicolumn{1}{c}{$\mathrm{R}_{1}$} & \multicolumn{1}{c}{$\mathrm{R}_{2}$} & $\mathrm{IC}_{50}(\mathrm{nM})$ \\
\hline$-\mathrm{COCH}_{2} \mathrm{OH}$ & $\alpha$-L-rhamnose & 1070 \\
$-\mathrm{CH}_{2} \mathrm{OH}$ & $\alpha$-L-rhamnose & 360 \\
$-\mathrm{CH}_{2} \mathrm{NH}_{2} \cdot \mathrm{HCl}$ & $\alpha$-L-rhamnose & 99 \\
$-\mathrm{CH}_{2} \mathrm{NO}_{2}$ & $\alpha$-L-rhamnose & 12 \\
$-\mathrm{CH}_{2} \mathrm{CH}_{2} \mathrm{NO}_{2}$ & $\alpha$-L-rhamnose & 45 \\
$-\mathrm{CH}_{2} \mathrm{NH}_{2} \cdot \mathrm{HCl}$ & $\beta$-D-digitoxose & 270 \\
$-\mathrm{CH}_{2} \mathrm{NO}_{2}$ & $\beta$-D-digitoxose & 88
\end{tabular}

Figure 18. Structure of some pregnane and 21-norpregnane derivatives. $\mathrm{IC}_{50}$ represents concentration inhibiting $50 \%$ of ${ }^{3} \mathrm{H}$-ouabain binding.

The nitro group has shown to be the best substituent, being genins much less potent than glycosides. Rhamnose is the sugar conferring the highest potency. Related to the stereochemistry, $\beta$ disposition is most favourable. With these substituents, specifically, changing from $17 \beta$ to $17 \alpha$ implies a 20 -fold decrease in potency.

Comparison between pregnane ( $\alpha$ or $\beta$ ) and the corresponding 21-norpregnane derivatives indicates 
a higher potency for the latter [84]. This effect could be due either to the restriction in rotation produced by methyl at $\mathrm{C} 21$, preventing the tightest binding of C20 group, or to the own methyl preventing the strongest binding to receptor. Nevertheless, conformational study of these compounds shows, for 21-norderivatives, a closer conformation to less potent $20 \alpha$ than to more potent $20 \beta$. 20-nitro-14-

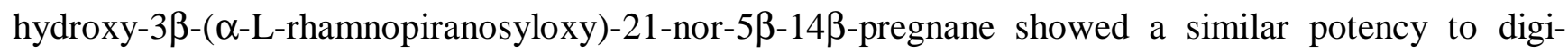
toxin in ${ }^{3} \mathrm{H}$-ouabain-binding displacement.

Preliminary studies indicate that some of these derivatives (nitro, amine) could have a better therapeutical index than digitoxin.

Pregnane derivatives bearing amine group at $\mathrm{C} 14 \beta$ and different moieties at $\mathrm{C} 3$ and $\mathrm{C} 17$ have been prepared [85]. Among them, the best therapeutical index has been shown by compound LND623 [86], being the $20 \alpha-\mathrm{OH}$ epimer more potent than the $20 \beta-\mathrm{OH}$ [87]; this suggest that only the $20 \alpha-\mathrm{OH}$ could accept a favourable Hydrogen bond, possibly acting through formation of one or two Hydrogen bonds.
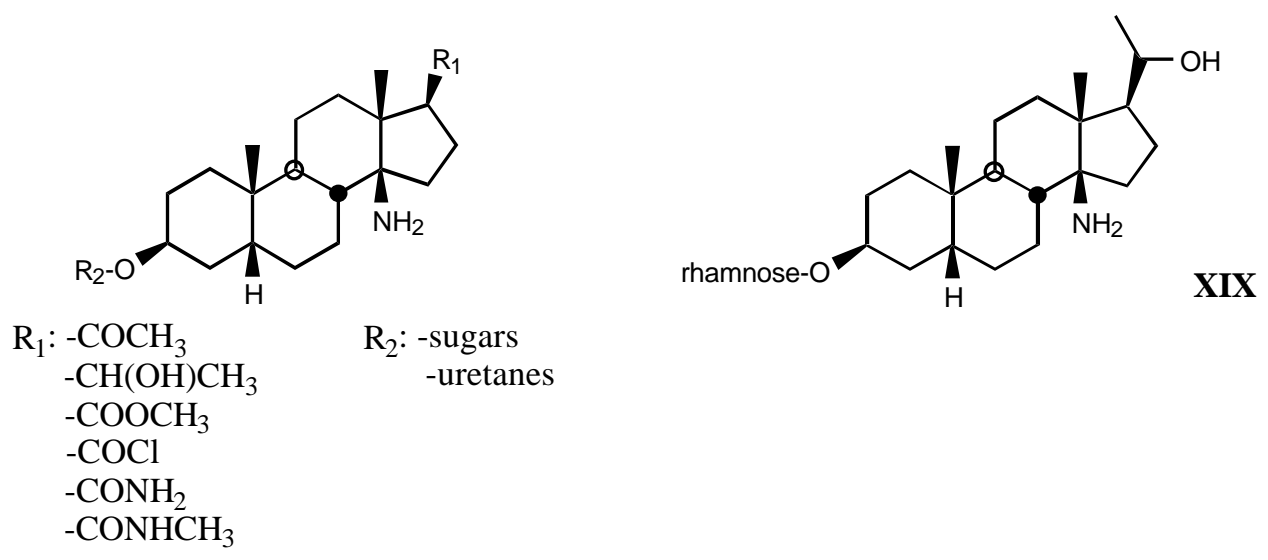

Figure 19. Structure of some $14 \beta$-aminopregnane derivatives.

Related to the stereochemistry of C/D rings junction, megestrol acetate and chlormadinol acetate (CMA), bearing C/D trans junction, inhibit $\mathrm{Na}^{+}, \mathrm{K}^{+}$-ATPase [88]. CMA showed a potency similar to digitoxigenin in in vitro ${ }^{3} \mathrm{H}$-ouabain binding assays.
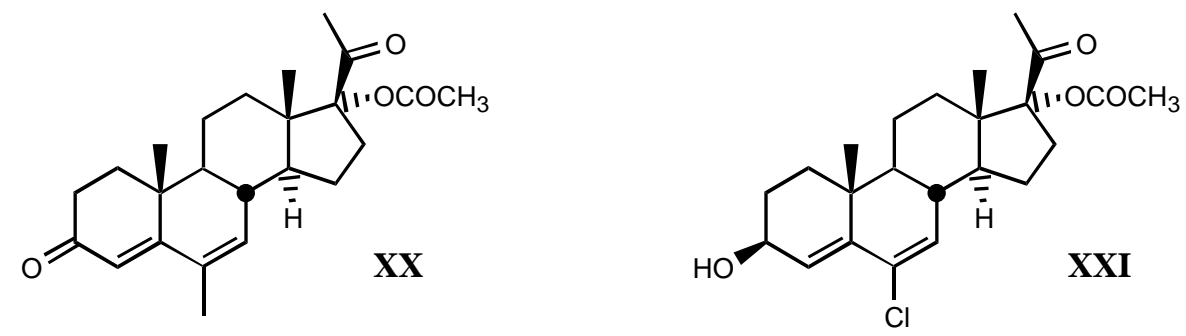

Figure 20. Structure of megestrol acetate (XX) and chlormadinol acetate (CMA, XXI).

A detailed analysis of the CMA structure [89] indicates that, overlapping B and C rings onto those 
of digitoxigenin places the $\mathrm{C} 20$ carbonyl group of CMA close to the lactone carbonyl of digitoxigenin. CMA displayed a negative inotropic effect in contractility assays, being turned into positive when glycosidated at $\mathrm{C} 3$, possibly because in that way its ability to go into the cell and produce intracellular effects that give rise to negative inotropy was reduced [82b] [90]. Spirolactones, with also C/D trans junction, display a positive inotropic activity as well [91].

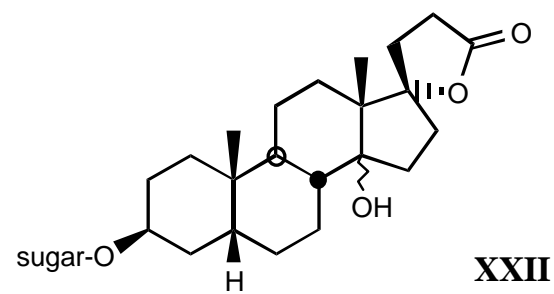

Figure 21. Structure of spirolactone (XXII).

On the other hand, recent studies carried out on $17 \beta$ - $(O$-aminoalkyl $)$-oxime derivatives [92] showed that $\mathrm{C} / \mathrm{D}$ trans analogues are significantly less potent than the corresponding C/D cis, although only slightly less potent than digoxin.
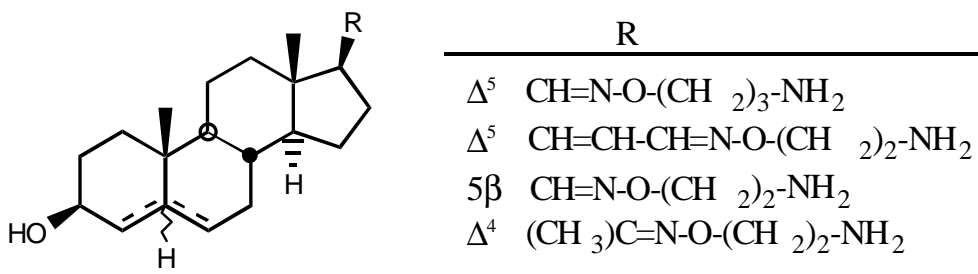

Figure 22. Structure of some C/D trans derivatives.

Because all the aforecited considerations, further research is needed in order to know the influence of $\mathrm{C} / \mathrm{D}$ junction on digitalis-like activity.

\subsection{Endogenous digitalis-like factors}

The digitalis binding site is strongly conserved in a wide variety of organisms. This fact, together with its high sensitivity to low substrate concentrations and high specificity of interaction substratereceptor, has given rise to the speculation of binding site being a receptor for an endogenous ligand, in the same way as the opioid receptor gave rise to idea and further discovery of endogenous opioids (endorphins and enkephalins). The ability of some animal species to synthesize cardiotonic steroids, e.g. toads, shows that vertebrates are able to synthesize steroids with digitalis structure.

Systematic search for such endogenous digitalis-like compounds was started by Szent-Györgyi in 1953 [93]. Since then, a large amount of EDLF (endogenous digitalis-like factors) have been described [94], having been their levels related to hypertension in animal and human models. Most recent results 
point to ouabain-like factors (OLF) [95], probably ouabain stereoisomers, isolated from hypothalamus [96] and human plasma [97], which are increased in certain types of hypertension [98].

Nevertheless, it has to be taken into account the possibility of an alteration of putative ELDF during its isolation, as well as it is possible that extracted compounds are precursors or metabolites eliciting a lower activity than the primary ligand (specially when they have been isolated from urine).

The most suitable test for classifying a compound as digitalis-like factor is its ability to bind to the digitalis receptor. So, hypothalamic inhibitor has shown negative results [99]. They seem to be several physiological $\mathrm{Na}^{+}, \mathrm{K}^{+}$-ATPase inhibitors, which have not necessarily a structural relationship with digitalis compounds [100].

However, some authors are uncertain about the existence of such an inhibitor and its role in hypertension [101], indicating that it is possible that the digitalis receptor is only an enzyme feature needed for its activity as cationic pump. Moreover, it is argued that isolated EDLF amounts are so small that they do not seem to be important for playing a physiological role, even when it can be considered the possibility of a located release or a selective affinity for one of $\mathrm{Na}^{+}, \mathrm{K}^{+}$-ATPase isoenzymes. Another argument is that cardiac glycosides do not produce hypertension at therapeutic doses. Some authors even speculate with certain C/D trans steroidal hormones as models for the chemical structure of endogenous digitalis [88]. They have also been proposed synthetic candidates as EDLF analogues [102].

Although there are many results supporting the existence of an endogenous $\mathrm{Na}^{+}, \mathrm{K}^{+}$-ATPase inhibitor in physiological situations and in pathogenesis of hypertension and other diseases, many questions remain to answer [103], so further research is needed to definitively stablish the existence of such an inhibitor.

\section{Digitalis Analogues Bearing Aminoguanidine Moieties}

\subsection{Aminoguanidine moiety in drugs}

Aminoguanidine is present in a wide variety of drugs eliciting very different activities. Its most characteristic feature is a high basicity, arising from its ability to delocalize the positive charge of protonated derivatives on three guanidine Nitrogen atoms [104]. However, most of these compounds displaying a pharmacological activity are not strong bases, since any electron-withdrawing group bound to any of the Nitrogen atoms decreases dramatically basicity [105].

Among therapeutic groups including aminoguanidine derivatives appear adrenergic agonists (aganodine), antihypertensives (guanabenz, guanoxabenz, idralfidine), antiiflammatory and analgesic drugs (praxadine, apazone), antibacterials (ambazone, chloroazodine), antiparasitic drugs (robenidine), antineoplastic compounds (bisantrene, mitoguazone), antihistamine, antivirals, platelet inhibitors, antiarrhytmic, inmunosuppressors... [106].

Aminoguanidine by itself also displays pharmacological activities, such as nitric oxide synthase inhibition, histidine decarboxylase inhibition, catalase inhibition, diamine oxidase inhibition, glycation 
inhibition, S-adenosylmethionin decarboxylase inhibition, antioxidant activity, antiaterogenic effect, etc.

\subsection{Aminoguanidines in digitalis compounds}

Among guanylhydrazone derivatives displaying cardiotonic activity, the 3,20-bisguanylhydrazones of prednisone and prednisolone (PGB) have shown activity related to inotropic effect and $\mathrm{Na}^{+}, \mathrm{K}^{+}$ATPase inhibition, even without bearing any of structural requirements that seem to be essential for classic cardiotonic steroids.

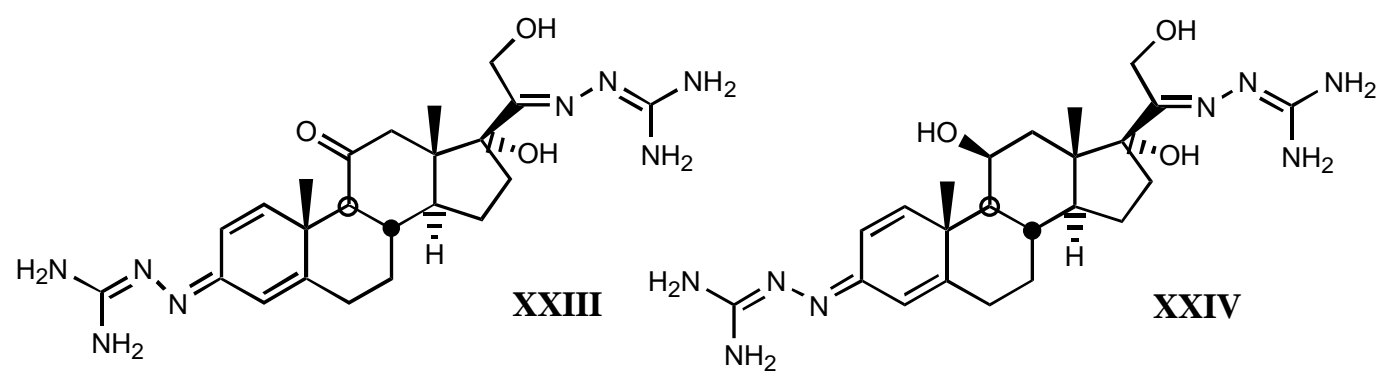

Figure 23. Structure of 3,20-guanylhydrazones of prednisone (XXIII) and prednisolone (XXIV).

It was later observed that PGB differs from ouabain in not showing high and low affinity for different $\mathrm{Na}^{+}, \mathrm{K}^{+}$-ATPase isoenzymes, although it showed large differences related to potency if different species are considered, and it also inhibited ${ }^{3} \mathrm{H}$-ouabain binding [107]. This can be interpreted as either PGB binds to the digitalis receptor, but some parts of the enzyme not affecting to isoenzyme differentiation are involved, or it binds to a different site from digitalis receptor and then induces conformational changes inhibiting ouabain binding.

The guanylhydrazone moiety is a strong base, so bisguanylhydrazones can act as biscationic compounds, having then the steroid a passive role as bridge between such cations. That possibility is supported by the fact that changes in steroidal framework, related to stereochemistry or substituents attached to it, do not affect significatively its activity [108], while it does for digitalis glycosides. Bisguanylhydrazone of $5 \beta$ - or $5 \alpha$-pregnanedione do not show a significative difference related to their activity. Enzyme sequentiation stablishes that the first and second extracellular segments bear several aminoacids carrying free carboxylic groups [109], which could interact with both guanylhydrazone ends of the compound.

However, replacement of digitoxigenin lactone ring by a guanylhydrazone group results in a compound with decreased digitalis-like activity (about $20 \%$ of parent compound), which showed a high sensitivity to modification in steroidal framework, indicating a possible binding to digitalis receptor [39]. If so, it could indicate that such receptor would include a moiety able to display a strong electrostatic interaction with the guanylhydrazone cation. It has to be pointed out that the corresponding semicarbazone, similar but non-ionic, does not elicit any activity. 

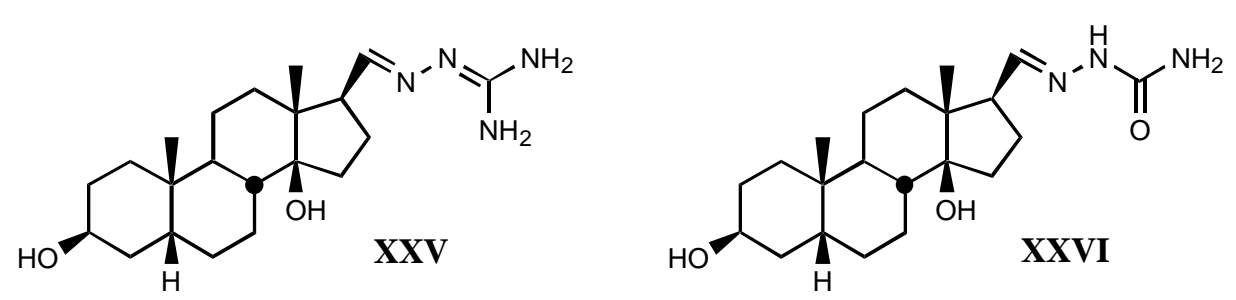

Figure 24. Structure of guanylhydrazone (XXV) and semicarbazone (XXVI) of digitoxigenin.

The activity of some monoguanylhydrazones at C17 of the pregnane system [110] (bearing C/D trans junction and variability in $\mathrm{A} / \mathrm{B}$ junction -cis, trans, quasiplanar-) have also been studied. These compounds inhibit $\mathrm{Na}^{+}, \mathrm{K}^{+}$-ATPase, but they produce a transient increase of myocardial contractility followed by a strong negative inotropic effect.

So, related to the influence of C/D junction on the activity of 20-guanylhydrazones, the C/D cis junction confers specificity of action, whereas the guanylhydrazone side-chain confers on the steroid with a C/D trans junction the non-specific ability to inhibit various ATPases.

A wide variety of 3,20-bisguanylhydrazones display a positive inotropic effect on cardiac muscle. The variation of distance between both guanylhydrazone moieties by modification of attachment position at the steroidal framework does not alter, within certain limits, activity. Moreover, some bisguanylhydrazones of non-steroidal molecules also display cardiotonic activity; e.g., some diphenylbisguanylhydrazones and bisguanylhydrazones of bi- and tricyclic molecules are active [108].

On the other hand, certain monoguanylhydrazones at position C3 are also active. Specifically, 3guanylhydrazone of 3-oxodigitoxigenin is active, while 3-guanylhydrazone of the corresponding 14deoxy-14 $\alpha$-cardenolide is not.
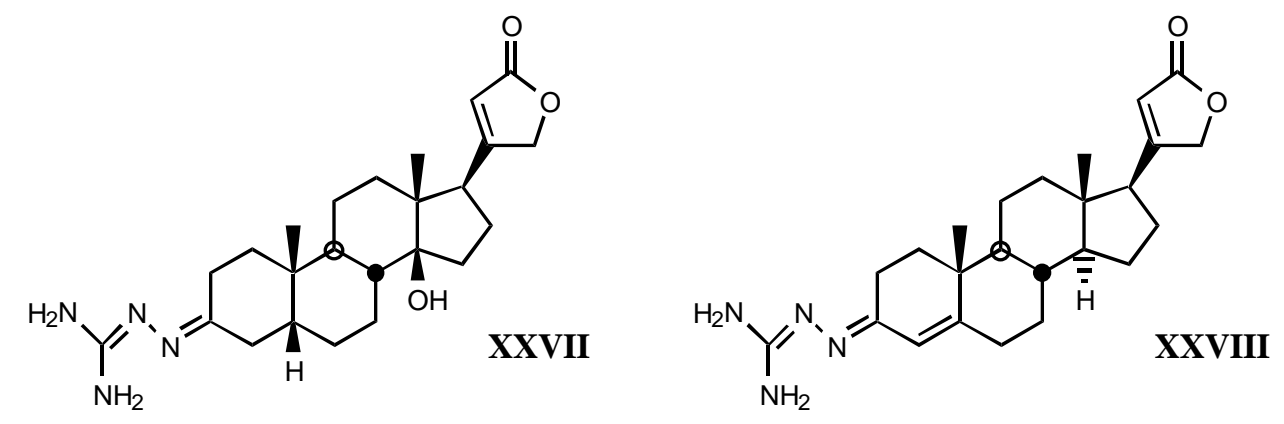

Figure 25. Structure of 3-guanylhydrazones of 3-oxodigitoxigenin (XXVI) and 14-deoxy-14 $\alpha$ digitoxigenin (XXVII).

Hydrogenation of guanylhydrazone moiety to yield bisguanidineamine derivatives does not involve a significative loss of activity. Nevertheless, replacement of such guanylhydrazone by other related structures, as hydrazine or S-methylthiosemicarbazone, gives inactive compounds.

Pharmacological assays carried out with 3,20-bisguanylhydrazones indicate that therapeutical in- 
dexes for these compounds are about two times better than those of natural cardiac glycosides are.

Among all these derivatives, the 3,20-bisguanylhydrazone of triamcinolone was selected to carry out pharmacological assays on human beings, for having shown best results in animal models. Nevertheless, although results on cardiac function were satisfactory, increasing the outgoing cardiac flow in $32 \%$ without giving rise to bradycardia, its too short-lasting action made it a non-suitable substitute for digitalis.

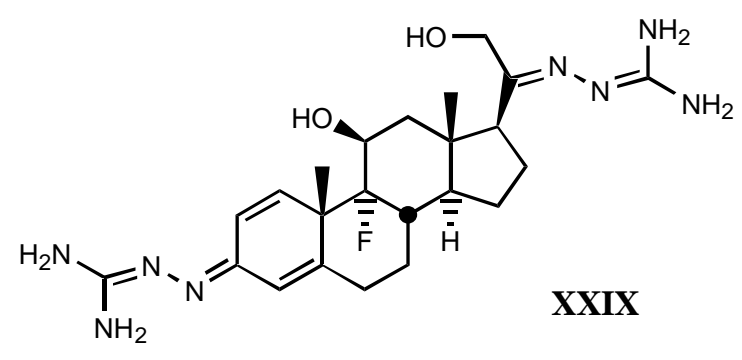

Figure 26. Structure of 3,10-bisguanylhydrazone of triamcinolone (XXIX).

In the same way, some studies on the guanylhydrazone of 2-digitoxigenone and several Schiff bases of 3-digitoxigenone have been carried out [111], using guinea-pig atria for inotropism assays and ${ }^{3} \mathrm{H}$ ouabain displacement as a measure of interaction with digitalis receptor. These compounds showed an intermediate activity between 3-digitoxigenone and ouabagenin. Although absolute potency of these derivatives varies depending on the considered species, the relative order of potency remains similar for all of them, indicating that they do not show any special preference for one of the isoenzymes in any of studied species.

Among the simplified, non-steroidal, digitalis glycosides analogues, the guanylhydrazone and bisguanylhydrazone derivatives of $\mathrm{C} / \mathrm{D}$ cis hydroindenes have shown the best results, significantly improving contractile force without affecting the cardiac rate [55].

The first and second $\mathrm{Na}^{+}, \mathrm{K}^{+}$-ATPase extracellular fragments are thought to be responsible of digitalis binding to enzyme [112]. These fragments bear aminoacids carrying six free carboxylic acids, giving rise to different binding ways to ligands bearing different ionisation degrees. Because of that, it is interesting to study the influence of basicity of substituents attached to the digitalis steroidal framework. So, a large amount of cardenolide analogues, carrying a guanylhydrazone moiety or derivatives of it replacing the lactone ring, have been synthesized; QSAR studies on several of these compounds have been carried out [83f, 67] [113], from which the following conclusions have been extracted:

* A good correlation is observed between receptor binding and Van der Waals volume and molar refractivity of different fragments including guanylhydrazone or derivatives of it attached to position $\mathrm{C} 17 \beta$ of digitalis compounds, as well as between such a binding and $\mathrm{pK}_{\mathrm{a}}$ and PA (proton affinity) values. The two later parameters are the most important related to the affinity showed by these compounds. 
* The positive charge borne by guanylhydrazone (or derivatives) moiety is a very significant factor. The more protonated it is, the higher is the affinity. This one also rises with basicity.

* Increasing of substituent bulk, especially when it is accompanied by an increase in the delocalization of $\pi$-electrons, produces a decreased affinity, indicating that either the receptor volume for this fragment is small, or decreasing of substituent bulk allows stronger electrostatic interactions between enzyme carboxylate and the protonated hydrazone of ligand.

Other studies indicate that alkyl or aryl derivatives of guanidinium act as competitive antagonists of $\mathrm{Na}^{+}$ions at $\mathrm{Na}^{+}, \mathrm{K}^{+}$-ATPase, then blocking occlusion and active cation transport [114]. Among them, those bearing two guanidine groups are more effective (about two times) than those with just one, being hydrophobicity of the molecule, rather than distance between guanidine groups, determinant for binding affinity. These derivatives act by stabilisation of $\mathrm{E}_{1}$ enzyme conformation, binding to it at the cytoplasmic side.

In summary, it seems likely that steroidal guanylhydrazones inhibit $\mathrm{Na}^{+}, \mathrm{K}^{+}$-ATPase by binding to the digitalis receptor. It is significant that derivatives bearing open chains, lactone ring isosters, are more effective than guanylhydrazone derivatives when bound to "classical" cardiotonic steroids, but they are inactive if bound to C/D trans steroids. This suggests that a close proximity to the receptor is more decisive for lactone isosters than for guanylhydrazone derivatives, so the main importance of $\mathrm{C} / \mathrm{D}$ cis configuration in classic cardiotonic compounds rises from their ability to place the lactone ring very close to receptor. This argument is not valid for bisguanylhydrazones of 3,20-diketosteroids, which produce enzyme inhibition, but by a different mechanism than that involved in the binding of cardiac glycosides to the digitalis receptor [84].

Acknowledgements: authors thanks the financial support from Junta de Castilla y Leon SA 02/99. C.P.L. thanks the Spanish M.E.C. a predoctoral grant.

\section{References and Notes}

1. Withering, W. An Account of the Foxglove and Some of its Medical Uses; M. Swynney: London, 1785 .

2. Ferriar, J. An Essay on the Medical Properties of the Digitalis purpurea or foxglove. Sowler and Russell: Manchester, 1799.

3. Haack, E.; Kaiser, F.; Gube, M.; Springler, H. Arzneim. Forsch. 1956, 6, 176-182.

4. Although lactone rings of cardenolides and bufadienolides, $\gamma$-crotonolactone and $\alpha$-pirone, easily react with thiol groups, Michael addition reactions to the butenolide ring of cardenolides have not been observed. 
5. Repke, K.R.H.; Schönfeld, W.; Weiland, J.; Megges, R.; Hache, A. In Design of Enzyme Inhibitors as Drugs; Sandler, M.; Smith, H.J., Eds.; Oxford University Press: Oxford, 1989; pp 435-502.

6. Thomas, R.E; Gray, P.; Andrews, J. In Advances in Drug Research; Testa, L.B., Ed.; Academic Press: London, 1990; Vol. 19, pp 313-575.

7. Blaustein, M.P. Rev. Physiol. Biochem. Pharmacol. 1974, 70, 33-82.

8. Skou, J.C. Biochim. Biophys. Acta 1957, 23, 394-401.

9. a) Jorgensen, P.L.; Andersen, J.P. J. Membr. Biol. 1988, 103, 95-120; b) Modyanov, N.; Lutsenko, S.; Chertova, E.; Efremov, R.; Gulyaev, E. Acta Physiol. Scand. 1992, 146, 49-58.

10. Skou, J.C. Ann. N. Y. Acad. Sci. 1982, 402, 169-184.

11. Heijne, G.V.; Gavel, Y. Eur. J. Biochem. 1988, 174, 671-678.

12. Kirley, T.L. J. Biol. Chem. 1989, 264, 7185-7192.

13. Geering, K. FEBS 1991, 285, 189-193.

14. Pedemonte, C.H.; Kaplan, J.H. Biochemistry 1992, 31, 10465-10470.

15. a) Béguin, P.; Wang, X.; Firsov, D.; Puoti, A.; Claeys, D.; Horisberger, J.D.; Geering, K. EMBO J. 1997, 16, 4250-4260; b) Minor, N.T.; Sha, Q.; Nichols, C.G.; Mercer, R.W. Proc. Natl. Acad. Sci USA 1998, 95, 6521-6525.

16. a) Collins, J.H.; Leszyk, J. Biochemistry 1987, 26, 8665-8668; b) Mercer, R.W.; Biemesderfer, D.; Bliss, D.P., Jr.; Collins, J.H.; Forbush, B., III. J. Cell Biol. 1993, 121, 579-586.

17. Cornelius, F.; Skou, J.C. Biochim. Biophys. Acta 1988, 944, 223-232.

18. Scheiner-Bobis, G.; Fahlbusch, K.; Schoner, W. J. Biochem. 1987, 168, 123-131.

19. Scheiner-Bobis, G., Buxbaum, E.; Schoner, W. In The $\mathrm{Na}^{+}, \mathrm{K}^{+}$-Pump, Part A: Molecular Aspects; Skou, J.C.; Nørby, J.G.; Maunsbach, A.B.; Esmann, M., Eds.; Alan R. Liss: New York, 1988; p 219.

20. a) Skriver, E.; Kaveus, U.; Hebert, H.; Maunsbach, A.B. J. Struct. Biol. 1992, 108, 176-185; b) Chetverin, A.B. FEBS Lett. 1986, 196, 121-125.

21. $\mathrm{Na}^{+}$and $\mathrm{K}^{+}$concentrations at rest are: $\left[\mathrm{Na}^{+}\right]_{\text {int. }}=7-20 \mathrm{mM},\left[\mathrm{Na}^{+}\right]_{\mathrm{ext}}=140 \mathrm{mM},\left[\mathrm{K}^{+}\right]_{\text {int. }}=110-120$ $\mathrm{mM},\left[\mathrm{K}^{+}\right]_{\mathrm{ext}}=4-5 \mathrm{mM}$.

22. Albers, R.W. Annu. Rev. Biochem. 1967, 36, 727-756.

23. Post, R.L.; Kume, S.; Tobin, T.; Orcutt, T.; Sen, A.K. J. Gen. Physiol. 1969, 54, 306S-326S.

24. Shull, G.E.; Schwartz, A.; Kingrel, J.B. Nature 1985, 316, 691-695.

25. Shamraj, O.I.; Lingrel, J.B. Proc. Natl. Acad. Sci. USA 1994, 91, 12952-12956.

26. Lingrel, J.B.; Orlowski, J.; Shull, M.M.; Price, E.M. Prog. Nucleic Acid Res. Mol. Biol. 1990, 38, 37-89.

27. Shyjan, A.W.; Gottardi, C.; Levenson, R. J. Biol. Chem. 1990, 265, 5166-5169.

28. a) Malik, N.; Canfield, V.A.; Beckers, M.C.; Gros, P.; Levenson, R. J. Biol. Chem. 1996, 271, 22754-22758; b) Yu, C.; Xie, Z.; Askari, A.; Modyanov, N.N. Arch. Biochem. Biophys. 1997, 345, 143-149.

29. Good, P.J.; Richter, K.; Dawid, I.B. Proc. Natl. Acad. Sci. USA 1990, 87, 9088-9092. 
30. a) Shull, M.M.; Lingrel, J.B. Proc. Natl. Acad. Sci. USA 1987, 84, 4039-4043; b) Shull, M.M.; Pugh, D.G.; Lingrel, J.B. J. Biol. Chem. 1989, 264, 17532-17543; c) Shull, M.M.; Pugh, D.G.; Lingrel, J.B. Genomics 1990, 6, 451-460; d) Lane, L.K.; Shull, M.M.; Whitmer, K.R.; Lingrel, J.B. Genomics 1989, 5, 445-453; e) Yang, F.T.; Schneider, J.W.; Lindgren, V.; Shull, M.M.; Benz, E., Jr.; Lingrel, J.B.; Francke, U. Genomics 1988, 2, 128-138.

31. Levenson, R. Rev. Physiol. Biochem. Pharmacol. 1994, 123, 1-45.

32. Geering, K. Curr. Op. Nephrol. Hypertens. 1997, 6, 434-439.

33. Thomas, R.E. In Molecular Structure and Biological Activity of Steroids; Bohl, M., Daux, W.L., Eds.; CRC Press: Boca Raton, 1992; pp 399-464.

34. Lee, C.O. Am. J. Physiol. 1985, 249, 367-378.

35. Gillis, R.A.; Quest, J.A. In Cardiac Glycosides; Erdmann, E., Greeff, K., Skou, J.C., Eds.; Steinkopff: Darmstadt, 1986; pp 347-356.

36. Steyn, P.S.; van Heerden, F.R. Nat. Prod. Reports 1988, 15, 397-413.

37. a) Fieser, L.F.; Fieser, M. In Natural Products Related to Phenantrene; Reinold corp: New York, 1949; pp 507-577; b) Sivadijan, J. In Traité de Chimie Organique; Grignard, V.; Dupont, G.; Locquin, R., Eds.; Masson: Paris, 1949; pp 1076-1079.

38. a) Deepak, D.; Srivastava, S.; Khare, N.K.; Khare, A. Fortsch. Chem. Org. Naturst. 1996, 69, 71155; b) Gaignault, J.C.; Bidet, D. Fitoterapia 1988, 59, 259-315.

39. Imre, Z.; Yurdun, T. Planta Medica 1988, 54, 529-531.

40. Pieri, F.; Arnould-Guerin, M.L.; Sefraoni, E.H. Fitoterapia 1992, 63, 333-336.

41. Cheung, H.T.A.; Nelson, C.J. J. Chem. Soc. Perkin Trans. I 1989, 1563-1570.

42. Gil, R.R.; Lin, L.Z.; Chai, H.B.; Pezzuto, J.M.; Cordell, G.A. J. Nat. Products 1995, 58, 848-856.

43. Umehara, K; Sumii, N.; Satoh, H.; Miyase, T.; Kuroyagani, M.; Ueno, A. Chem Pharm. Bull. 1995, 43, 1565-1568.

44. Abe, F.; Yamauchi, T. Chem. Pharm. Bull. 1994, 42, 2028-2031.

45. a) Thomas, R.E.; Gray, P.; Andrews, J. In Advances in Drug Research; Testa, L.B., Ed.; Academic Press: London, 1990; Vol. 19, pp 313-575; b) Thomas, R.E. In Burger's Medicinal Chemistry and Drug Discovery, 5th ed.; Wolff, M.E., Ed.; John Wiley\&Sons: New York, 1996; Vol. 2, pp 153-261; c) Repke, K.R.H.; Weiland, J.; Megges, R. In Progress in Medicinal Chemistry; Ellis, G.P.; Luscombe, D.K., Eds.; Elsevier: Amsterdam, 1993; Vol. 30, pp 135-202; d) Repke, K.R.H.; Weiland, J.; Megges, R. Angew. Chem. Int. Ed. Engl. 1995, 34, 282-294; e) Bohl, M.; Süssmilch, R. Eur. J. Med. Chem. 1986, 21, 193-198; f) Repke, K.R.H., Weiland, J.; Megges, R.; Schon, R.; J. Enzyme Inhib. 1996, 10, 147-157.

46. a) Schönfeld, W.; Weiland, J.; Lindig, C.; Masnyk, M.; Kabat, M.M.; Kurek, A.; Wicha, J.; Repke, K.R.H. Naunyn-Schmiedeberg's Arch. Pharmacol. 1985, 329, 414-426; b) Repke, K.R.H. Trends Pharmacol. Sci. 1985, 6, 275-278.

47. Burt, S.K.; Mackay, D.; Hagler, A.T. In Computer-Aided Drug Design: Methods and Applications; Perun, T.J.; Propts, C.L., Eds.; Marcel Dekker: New York, 1989; pp 55-91. 
48. Schönfeld, W.; Schönfeld, R.; Menke, K.H.; Weiland, J.; Repke, K.R.H. Biochem. Pharmacol. 1986, 35, 3221-3231.

49. Shigei, T.; Tsuru, H.; Saito, Y.; Okada, M. Experientia 1973, 29, 449-450.

50. a) Griffin J.F.; Rohrer, D.C.; Ahmed, K.; From. A.H.L.; Hashimoto, T.; Rathore, H.; Fullerton, D.S. Mol. Pharmacol. 1986, 29, 270-274; b) Hashimoto, T.; Rathore, H.; Satoh, D.; Hong, G.; Griffin, J.F.; From, A.H.L.; Ahmed, K.; Fullerton, D.S. J. Med. Chem. 1986, 29, 997-1003.

51. Gobbini, M.; Benicchio, A.; Marazzi, G.; Padoani, G.; Torri, M.; Melloni, P. Steroids 1996, 61, 572-582.

52. San Feliciano, A.; Medarde, M.; Caballero, E.; Hebrero, B.; Tomé, F. Tetrahedron 1990, 46, 6789-6798.

53. a) Medarde, M.; Caballero, E.; Tomé, F.; Gracia, P.G.; Boya, M.; San Feliciano, A. Synth. Commun. 1995, 25, 1377-1382; b) Medarde, M.; Tomé, F.; López, J.L.; Caballero, E.; Boya, M.; Melero, C.P.; San Feliciano, A. Tetrahedron Lett. 1994, 35, 8683-8686; c) Medarde, M.; Caballero, E.; Melero, C.P.; Tomé, F.; San Feliciano, A. Tetrahedron: Asymmetry 1997, 8, 2075-2077.

54. Melero, C.P. Ph.D. disertation. Universidad de Salamanca, 1999.

55. a) Melero, C.P.; Sevillano, L.G.; Caballero, E.; Tomé, F.; Carrón, R.; Montero, M.J.; San Feliciano, A.; Medarde, M. Bioorg. Med. Chem. Lett. 1998, 8, 3217-3222; b) Sevillano, L.G.; Melero, C.P.; Boya, M.; López, J.L.; Tomé, F.; Caballero, E.; Carrón, R.; Montero, M.J.; Medarde, M.; San Feliciano, A. Bioorg. Med. Chem. 1999 (in press).

56. Smith, P.; Brown, L.; Boutagy, J.; Thomas, R.E. J. Med. Chem. 1982, 25, 1222-1226.

57. Schönfeld, W.; Repke, K.R.H. Quant. Struct.-Act. Relat. 1988, 7, 160-165.

58. a) Kahn, J.B.; Acheson, G.H. J. Pharmacol. Exp. Ther. 1955, 115, 301-318; b) Guzmán, A.; Muchowski, J.M.; Strosberg, A.M.; Sims, J.M. Can J. Chem. 1981, 59, 3241-3247; c) San Feliciano, A.; Medarde, M.; Caballero, C.; Hebrero, M.B.; Tomé, F.; Prieto, P.; Montero, M.J. Eur. J. Med. Chem. 1990, 25, 413-417; d) Medarde, M.; Caballero, E.; Tomé, F.; García, A.; Montero, M.J.; Carrón, R.; San Feliciano, A. Eur. J. Med. Chem. 1993, 28, 887-892.

59. Bohl, M.; Süssmilch, R. Eur. J. Med. Chem., Chim. Ther. 1986, 21, 193-198.

60. Boobbyer, D.N.A.; Goodford, P.J.; McWhinnie, P.M.; Wade, R.C. J. Med. Chem. 1989, 32, 10831094.

61. a) Pastelin, G.; Méndez, R. Life Sci. 1983, 32, 1905-1909; b) Staroske, T.; Henning, L.; Welzel, P.; Hofmann, H.J.; Müller, D.; Haüsler, T.; Sheldrick, W.S.; Zillikens, S.; Gretzer, B.; Pusch, H.; Glitsch, H.G. Tetrahedron 1996, 52, 12723-12744.

62. a) Fullerton, D.S.; Yoshioka, K.; Rohrer, D.C.; From, A.H.L.; Ahmed, K. Science 1979, 205, 917919; b) From, A.H.L.; Fullerton, D.S.; Deffo, T.; Kitatsuji, E.; Rohrer, D.C.; Ahmed, A. J. Mol. Cell. Cardiol. 1984, 16, 835-842.

63. Fullerton, D.S.; Yoshioka, K.; Rohrer, D.C.; From, A.H.L.; Ahmed, K. Mol. Pharmacol. 1980, 17, 43-51.

64. Fullerton, D.S.; Ahmed, K.; From, A.H.L., McParland, R.H.; Rohrer, D.C.; Griffin, J.F. In Mo- 
lecular Graphics and Drug Design; Burgen, A.S.V.; Roberts, G.C.K.; Tute, M.S., Eds.; Elsevier: Amsterdam, 1986; pp 257-284.

65. Scrocco, E.; Tomasi, J. Adv. Quantum Chem. 1978, 11, 115-194.

66. Theil, F.; Lindig, C.; Repke, K.R.H. J. Prakt. Chem. 1980, 322, 1012-1020.

67. Thomas, R.E.; Boutagy, J.; Gelbart, A. J. Pharm. Exp. Ther. 1974, 191, 219-231.

68. Fullerton, D.S.; Yoshioka, K.; Rohrer, D.C.; From, A.H.L.; Ahmed, K. J. Med. Chem. 1979, 22, 529-533.

69. Akera, T. In Cardiac Glycosydes, Part I, Experimental Pharmacology; Greeff, K., Ed.; Springer: Berlin, 1981; Vol. 56, I, pp 287-336.

70. a) Chiu, F.C.K.; Watson, R.T. J. Med. Chem. 1985, 28, 509-515; b) Yoda, A. Mol. Pharmacol. 1973, 9, 51-60.

71. Fullerton, D.S.; Kihara, M.; Deffo, T.; Kitatsuji, E.; Ahmed, K.; Simat, B.; From, A.H.L.; Rohrer, D.C. J. Med. Chem. 1984, 27, 256-261.

72. Rathore, H.; From, A.H.L.; Ahmed, K.; Fullerton, D.S. J. Med. Chem. 1986, 29, 1945-1952.

73. Brown, L.; Thomas, R.E. Arzneim. Forsch. 1983, 33, 814-817.

74. Randimbivololona, F.; Pellegrin, P.; Lesne, M. J. Pharm. Belg. 1984, 39, 225-232.

75. From, A.H.L.; Fullerton, D.S.; Ahmed, K. Mol. Cell Biochem. 1990, 94, 157-165.

76. Gobbini, M.; Benicchio, A.; Padoani, G.; Torri, M.; Melloni, P. Biorg. Med. Chem. Lett. 1997, 7, 469-472.

77. Kyte, J. J. Biol. Chem. 1972, 247, 7634-7641.

78. Jarreau, F.X.; Koening, J.J. European Patent, 1979, EP 3455.

79. Ippolito, J.A.; Alexander, R.S.; Christianson, D.W. J. Mol. Biol. 1990, 215, 457-471.

80. Hansen, O. Pharmacol. Rev. 1984, 36, 143-163.

81. a) Sakakibara, M.; Uchida, A.O. Biosci. Biotech. Biochemistry 1996, 60, 405-410; b) Sakakibara, M.; Uchida, A.O. Biosci. Biotech. Biochemistry 1996, 60, 411-414; c) LaBella, F.S.; Templeton, J.F. Clin. Exp. Hypertens. 1998, 20, 601-609.

82. a) Kim, R.S.; LaBella, F.S.; Zunza, H.; Zunza, F.; Templeton, J.F. Mol. Pharmacol. 1980, 18, 402-405; b) LaBella, F.S.; Bihler, I.; Templeton J.F.; Kim, R.S.; Hnatowich, M.; Rohrer, D.C. Fed. Proc. 1985, 44, 2806-2811.

83. a) Templeton, J.F.; Ling, Y.; Marat, K.; LaBella, F.S. J. Med. Chem. 1997, 40, 1439-1446; b) Templeton, J.F.; Kumar, V.P.S.; Bose, D.; LaBella, F.S. J. Med. Chem. 1989, 32, 1977-1981; c) Templeton, J.F.; Ling, Y.; Jin, J.; Boehmer, M.A.; Zeglam, T.H.; LaBella, F.S. J. Chem. Soc. Perkin Trans. I 1991, 823-829; d) Templeton, J.F.; Kumar, V.P.S.; Bose, D.; Smyth, D.D.; Kim, R.S.; LaBella, F.S. Can. J. Physio. Pharmacol. 1988, 66, 1420-1424; e) Smyth, D.D.; Templeton, J.F.; Kumar, V.P.S.; Yan, Y.; Widajewicz, W.; LaBella, F.S. Can. J. Physiol Pharmacol. 1992, 70, 723-727; f) Templeton, J.F.; Ling, Y.; Zeglam, T.H.; Marat, K.; LaBella, F.S. J. Chem. Soc. Perkin Trans. I 1992, 2503-2517.

84. Templeton, J.F.; Ling, Y.; Zeglam, T.H.; LaBella, F.S. J. Med. Chem. 1993, 36, 42-45. 
85. Annual Drug Data Report; J.R. Prous Science Publishers: Barcelona, 1995; p 912.

86. Maixent, J.M.; Berrebi-Bertrand, I.; Lelièvre, L.G.; Fenard, S. Arzneim. Forsch. 1992, 42, 13011305.

87. Swynghedauw, B.; Jarreau, F.X.; Nittemberg, A.; Mouas, C.; Preteseille, M.; Lelièvre, L.G. J. Mol. Cell. Cardiol. 1983, 15 (suppl. 2), 55.

88. Repke, K.R.H.; Weiland, J.; Menke, K.H. J. Enzyme Inhib. 1991, 5, 25-32.

89. Fullerton, D.S.; Kitatsuji, E.; Deffo, T.; Rohrer, D.C.; Ahmed, K.; From. A.H.L. Curr. Top. Membr. Transp. 1983, 19, 257-264.

90. Weiland, J.; Schwabe, K.; Hübler, D.; Schönfeld, W.; Repke, K.R.H. J. Enzyme Inhib. 1987, 2, 31-36.

91. a) Silverstein, M.N.; Petit, R.M.; Solberg, L.M. Am. J. Med. 1992, 92, 69-72; b) Annual Data Drug Report; J.R. Prous Science Publishers: Barcelona 1995; p 914.

92. Quadri, L.; Barassi, P.; Gobbini, M.; Fedrizzi, G.; Santagostino, M.; Zappavigna, M.P.; Melloni, P. XVth Symposium on Medicinal Chemistry; Edinburgh (United Kingdom), 1998. Communication P.217.

93. Szent-Györgyi, A. Chemical Physiology of Contraction in Body Heart Muscle; Academic Press: New York, 1953; pp 79-88.

94. a) Goto, A.; Yamada, N.; Yagi, N.; Yoshioka, M.; Sugimoto, Y. Pharmacol. Rev. 1992, 44, 377399; b) Hamlyn, J.M.; Manunta, P. J. Hypertens. 1992, 10, S99-S111; c) Crambert, G.; Balzan, S.; Paci, A.; Decollogne, S.; Montali, U.; Ghione, S.; Lelièvre, L.G. Ann. N.Y. Acad. Sci. 1997, 834, 621-625.

95. Goto, A.; Yamada, K. Curr. Opin. Nephrol. Hypertens. 1998, 7, 189-196.

96. Tymiak, A.A.; Norman, J.A.; Bolgar, M.; Didonato, G.C.; Lee, H.; Parker, W.L.; Lo, L.C.; Berova, N.; Nakanishi, K.; Haber, E.; Haupert, G.T., Jr. Proc. Natl. Acad. Sci. USA 1993, 90, 8189-8193.

97. Hamlyn, J.M.; Blaustein, M.P.; Bova, S.; Ducharme, D.W.; Harris, D.W.; Mandel, F.; Mathews, W.R.; Ludens, J.H. Proc. Natl. Acad. Sci. USA 1991, 88, 6259-6263.

98. De Wardener, H.E. J. Hypertens. 1996, 14, S9-S18.

99. Carilli, C.T.; Berne, M.; Cantley, L.C.; Haupert, G.T. J. Biol. Chem. 1985, 260, 1027-1031.

100. Haupert, G.T. In The $\mathrm{Na}^{+}, \mathrm{K}^{+}$Pump, Part B: Cellular Aspects; Skou, J.C.; Nørby, J.G.; Maunsbach, A.B.; Esmann, M., Eds.; Alan R. Liss: New York, 1988; pp 297-320.

101. Kelly, R.A.; Smith, T.W. Adv. Pharmacol. 1994, 25, 263-288.

102. Paci, A.; Sakakibara, M.; Del Bene, P.; Uchida, A.O. Ann. N.Y. Acad. Sci. 1997, 834, 637-641.

103. a) Doris, P.A. Miner. Electrolyte Metab. 1996, 22, 303-310; b) Hollenberg, N.K.; Graves, S.W. In Progress in Drug Research; Birkhäuser Verlag: Basil, 1996; Vol. 46, pp 9-42; c) Pidgeon, G.B.; Lewis, L.K.; Yandle, T.G.; Richards, A.M.; Nicholls, M.G. J. Hypertens. 1996, 14, 169-171.

104. Greenhill, J.V.; Lue, P. In Progress in Medicinal Chemistry; Ellis, G.P.; Luscombe, D.K., Eds.; Elsevier: Amsterdam, 1993; Vol. 30, pp 203-326. 
105. Greenhill, J.V.; Ismail, M.J.; Edwards, P.N.; Taylor, P.J. J. Chem. Soc. Perkin Trans. II 1985, 1255-1264.

106. a) Bryant, H.U.; Nelson, D.L.; Button, D.; Cole, H.W.; Baez, M.B.; Lucaites, V.L.; Wainscott, D.B.; Whitesitt, C.; Reel, J.; Simon, R.; Koppel, G.A. Life Sci. 1996, 59, 1259-1268; b) Bubner, M.; Kasbohm, K.; Heise, K.H.; Richter, P.H. Pharmazie 1995, 50, 71-72; c) Dorhout, B.; Poortenga, P.J.; Kingma, A.W.; De Hoog, E.; Muskiet, F. Biochim. Biophys. Acta 1998, 1381, 95103; d) Desideri, N.; Sestili, I.; Piccardoni, P.; Rotondo, S.; Cerletti, C.; Stein, M.L. Arch. Pharm. (Weinheim) 1992, 325, 773-777; e) Diamant, S.; Agranat, I.; Goldblum, A.; Cohen, S.; Atlas, D. Biochem. Pharmacol. 1985, 34, 491-498; f) Doubell, P.C.; Oliver, D.W. Arzneim. Forsch. 1992, 42, 65-69; g) Mukhopadhyay, R.; Kapoor, P.; Madhubala, R. Pharmacol. Res. 1996, 33, 67-70.

107. Ng, Y.C.; Leung, W.Y.; Akera, T. Eur. J. Pharmacol. 1988, 155, 93-99.

108. Thomas, R.E.; Boutagy, J.; Gelbart, A. J. Pharm. Sci. 1974, 63, 1649-1683.

109. a) Lingrel, J.B.; Kuntzweiler, T.; J. Biol. Chem. 1994, 269, 19659-19662; b) Shull, G.E.; Lane, L.K.; Lingrel, J.B. Nature 1986, 321, 429-431.

110. Gelbart, A.; Thomas, R.E. J. Med. Chem. 1978, 21, 284-288.

111. Herber, D.; Herzig, S.; Moosig, F.; Neujahr, H. Pharmazie 1995, 50, 663-667.

112. Thomas, R.E.; Gray, P.; Andrews, J. Adv. Drug Res. 1990, 19, 814-839.

113. a) Cerri, A.; Serra, F.; Ferrari, P.; Folpini, E.; Padoani, G.; Melloni, P. J. Med. Chem. 1997, 40, 3484-3488; b) Schutz, S.; Meyer, K.; Kratzer, H. Arzneim. Forsch. 1969, 19, 69-75.

114. David, P.; Mayan, H.; Cohen, H.; Tal, D.M.; Karlish, S.J. J. Biol. Chem. 1992, 267, 1141-1149.

Sample availability: Samples in references 52-55 of this review are availables from authors

(C) 2000 by MDPI (http://www.mdpi.org). Reproduction is permitted for noncommercial purposes. 